\title{
Social- and Self-perception of Designers' Professional Identity
}

\author{
Kunrath, Kamila; Cash, Philip; Kleinsmann, Maaike
}

Published in:

Journal of Engineering Design

Link to article, DOI:

10.1080/09544828.2019.1676883

Publication date:

2020

Document Version

Peer reviewed version

Link back to DTU Orbit

Citation (APA):

Kunrath, K., Cash, P., \& Kleinsmann, M. (2020). Social- and Self-perception of Designers' Professional Identity. Journal of Engineering Design, 31(2), 100-126. https://doi.org/10.1080/09544828.2019.1676883

\section{General rights}

Copyright and moral rights for the publications made accessible in the public portal are retained by the authors and/or other copyright owners and it is a condition of accessing publications that users recognise and abide by the legal requirements associated with these rights.

- Users may download and print one copy of any publication from the public portal for the purpose of private study or research.

- You may not further distribute the material or use it for any profit-making activity or commercial gain

- You may freely distribute the URL identifying the publication in the public portal

If you believe that this document breaches copyright please contact us providing details, and we will remove access to the work immediately and investigate your claim 


\section{Social- and Self-perception of Designers' Professional Identity}

Kamila Kunrath ${ }^{\mathrm{a}}$, Philip Cash ${ }^{\mathrm{a} *}$ and Maaike Kleinsmann ${ }^{\mathrm{b}}$

Please cite as: K. Kunrath, P. Cash, and M. Kleinsmann, "Social- and Selfperception of Designers' Professional Identity", Journal of Engineering Design, IN PRESS, 2019. http://dx.doi.org/10.1080/09544828.2019.1676883.

${ }^{a}$ DTU Management, Technical University of Denamrk, Kgs. Lyngby, Denmark;

${ }^{b}$ Department of Product Innovation Management, Technical University of Delft, Delft, The Netherlands

Technical University of Denmark - Diplomvej 372, 2800 Kgs. Lyngby, Denmark pcas@dtu.dk, +45 45254550

Technical University of Delft - Landbergstraat 15, 2628 CE Delft, The Netherlands 


\section{Social- and Self-perception of Designers' Professional Identity}

Designers' Professional Identity (DPI) is a social- and self-perceptive construct that describes how designers understand themselves as professionals. DPI guides development throughout a designer's career by shaping professionalism, role assumptions, responsibilities, values and behaviour. DPI links two sets of elements: Personal Attributes and Design Skills. However, little is known about how designers perceive themselves in comparison to other critical actors affecting DPI: educators and managers. While differing perceptions between educators and managers is acknowledged, there is a critical need for more detailed understanding of these differences in comparison to how designers perceive themselves. This study uses semi-structured interviews with designers, design professors, and design managers to shed light on differences in perception of DPI. Analysis of the data highlights critical differences between the three groups. We described these differences with respect to three thematic perspectives on DPI: Technique, Creativity and Rapport. This provides important contributions to understanding DPI, with implications for education and practice.

Keywords: professional identity; psychology of design; design activity; design research; human factors

\section{Introduction}

Designer's Professional Identity (DPI) is a construct that describes how a designer, or a design engineer, self-identifies as a professional and understands their belonging to a professional group. This identification drives attitudes and behaviour (Cruess et al., 2016; Marquardt et al., 2016). Difficulties in the formation of DPI, particularly in the transition from education to practice, can significantly affect young professionals' early career and can impact their professional decision-making, e.g., commitment to the profession or decision to drop out (Lichtenstein et al., 2009). As such, it is critical to understand, in detail, how the self-perception of designers differs from that of professors and managers, as the major arbiters of social-perception in education and practice. 
The general construction of Professional Identity (PI) formally begins during higher education. Consequently, professors play a pivotal role in the initial development of their students' PI, based on their teaching of the norms they believe a student should adhere to, reinforced via academic assessment (Murphy, Chance, and Conlon 2015). As a result, students tend to align their perception of a profession with those of their professors (Trede, 2012a). When students enter the job market, the professor's influence is replaced by that of managers and peers. Interactions in the professional environment create the context in which professionals' develop and adapt their identity with respect to managerial practices, social norms, organisational culture (Crafford et al., 2015), and job performance assessment (Baumeister and Muraven 1996). As such, young professionals tend to align their views with those of their managers and peers. Problematically, professors' and managers' perceptions of a profession are often not well aligned, which can negatively impact the transition from the educational to professional environment (Bucciarelli and Kuhn 1997; Dall'Alba 2009). Critically, Fayard et al. (2017) highlight how much of a person's occupational mandate is developed in the professional environment rather than at university. This emphasises the need to study differences between managers and professors perspectives on PI, since it problematises the disconnect between education and practice. However, there is a critical gap in understanding the details of this misalignment with respect to the full range of designerly attributes and skills.

Little is known about exactly how professors' and managers' social-perception of DPI differ from the self-perception of designers. We close this gap by answering the following research questions: What are the social-and self-perceptions regarding the designer's role and the DPI elements? And what are the differences in the perceptions of professors and managers in comparison to designers with respect to i) overall 
importance of DPI elements, and ii) their relative importance at different phases during the NPD process? Throughout we use the term 'designer' to refer to design practitioners with a formal design engineering education. This definition reflects the research sample as well as accounting for the context and community of practice relevant to professional identification (Baumeister \& Muraven, 1996; Murphy et al., 2015). The results show substantial differences in the perspectives of professors and managers with respect to designers, particularly surrounding the prioritisation of creativity verses responsibility and customer service. As such, this work contributes to design theory, as well as providing implications for design education and practice.

\section{The factors influencing PI}

PI is described as the dynamic organisation of self- and social-perceptions (Skorikov and Vondracek 2011). This allows an individual to self-identify as a professional and drives their attitudes and behaviour in a professional context (Cruess et al., 2015; Marquardt et al., 2016). How the individual perceives him or herself as a professional is a reflection of self-awareness (Crossley \& Vivekananda-Schmidt, 2009) and is typically based on expectations of an 'ideal', seen as a goal to be achieved (Godsey, 2011; van Knippenberg et al., 2004). This guides the development of self-understanding and the sense of belonging to a professional group (Haslam and Ellemers 2011), which is integral to professional satisfaction and confidence (Skorikov \& Vondracek, 2011), competence and performance (Ashcraft 2013; Adams et al. 2011), career decisions (Lichtenstein et al. 2009), psychological wellbeing (Sharma and Sharma 2010) and mental health (De Goede et al. 1999). Thus, PI is directly related to professional development and is recognised through rewards and acknowledgments (Baumeister and Muraven 1996). 
Critically, the social context in which someone operates affects the formation of PI (Teixeira and Gomes 2000; Godsey, 2011; van Knippenberg et al., 2004), since interactions between individuals contribute to the development of self-understanding (Williams 2013). Self-perception and PI change and adapt to different career stages (M Dent and Whitehead 2001). In particular, PI evolves, from the educational to professional context. This captures the adaption from a professorial, academic perspective to a peer/manager perspective (Crafford et al., 2015). Peers shape PI by validating (or not) behaviours and providing feedback (Ibarra, 1999, p. 12). Sun, Williams, and Evans (2011) identifies the manager as primarily responsible for the professional's activities to ensure successful design work. Further, the professional environment and work activity shape expectations of professionals (D’Anjou 2011). Over time professionals tend to adapt their perceptions with respect to their peers and managers (Brunhaver et al., 2011), imitating their role models (Ibarra 1999). Thus, understanding the differing perspectives of designers, professors and managers is critical.

Adaptation to social-perceptions and common professional beliefs is critically linked to professional advancement and recognition (Baumeister and Muraven 1996). Understanding that different perspectives dominate different contexts helps to explain how PI is constructed. In particular, there is often a gap between students' expectations based on university programme requirements, and employers' demands (Wells et al., 2009). The transition from the educational to professional context requires fundamental changes to PI. This includes new skills, behaviours, attitudes and patterns of interaction (Ibarra 1999). Adaptation is needed to resolve discrepancies between the perceived 'ideal professional' and current PI. Thus, it is critical to understand the detailed 
differences in perception of DPI across the whole range of attributes and skills that contribute to a designers' identity.

\section{Methodology}

To evaluate these differences we adopt a detailed DPI framework, which consists of Personal Attributes (PA) and Design Skills (DS) (Kunrath, Cash, and Li-Ying 2017, 2016). Semi-structured interviews were held with designers and design engineers to evaluate self-perception, and design professors and design managers to evaluate socialperception ${ }^{1}$. Importantly, we focus on the contrast between these external groups and the group of designers as a whole. We do this due to the relative importance of professors and managers in shaping DPI (Sun 2011). As such, we do not evaluate the within group diversity of perspectives amongst 'peer' designers. The interviews addressed the following research questions:

1. What are the social- and self-perceptions regarding the designer's role and the DPI elements?

2. What are the differences in the perceptions of professors and managers in comparison to designers with respect to i) overall importance of DPI elements, and ii) their relative importance at different phases during the NPD process?

We synthesise insights from the extensive literature review reported by Kunrath et al. $(2016 ; 2017)$ in order to operationalise a list of elements capturing the widest range of relevant DPI constructs described in the design literature. Specifically, we separate confidence into self- and professional- aspects, as well as highlighting Motivation and

\footnotetext{
${ }^{1}$ In the remainder of the paper referred to as designers, professors and managers.
} 
Creativity as critical aspects of design work. While it is impossible to list every possible

element, by developing Tables 1 and 2 from the review of Kunrath et al. $(2016 ; 2017)$

we provide a robust list of, at least, the major DPI elements. Table 1 presents these

elements and the coding system used in this study. Table 2 presents the DPI elements

based on their descriptions in the literature.

Table 1. Categories and coding for DPI elements

\begin{tabular}{cclccl}
\hline DPI & Code & \multicolumn{1}{c}{ Name } & DPI & Code & Name \\
\hline PA & ET & Ethics & DS & CA & Cognitive Abilities \\
\hline PA & CR & Creativity & DS & CS & Cognitive Strategies \\
\hline PA & OP & Openness & DS & PC & Personal Communication \\
\hline PA & EM & Emotion & DS & IC & Interpersonal Communication \\
\hline PA & EP & Empathy & DS & EK & Knowledge from Education \\
\hline PA & SA & Social Abilities & DS & PK & Knowledge from Practice \\
\hline PA & LE & Leadership & DS & MC & Manager competency \\
\hline PA & RE & Responsibility & DS & PM & Project Management \\
\hline PA & MO & Motivation & & & \\
\hline PA & CO & Confidence in the work & & & \\
\hline PA & SC & Self-Confidence & & &
\end{tabular}

Table 2. Relation of DPI elements to design process

DPI element

Ethics

Creativity

Openness

Emotion

Empathy

PA

Social abilities

Leadership

Responsibility

Motivation

Self-Confidence

\section{Description from literature}

Professional understanding and taking responsibility for project outcomes, and how design solutions impact users and society (Cañavate et al. 2015)

Individual competency that can have a significant effect on design activity (Kim et al., 2011) as well as aspects of conceptualisation, including ideation, decision making and final solutions (Gonçalves, Cardoso, and Badke-schaub 2014) Open-mindedness and the capacity to deal with uncertainty or ambiguity (Ball \& Ormerod, 2000; Cross, 2004), flexibility (Brunello and Schlotter 2011)

An 'affect' based on background experiences, and a 'feeling' based on an awareness and knowledge of the affect (Rodger 1963). The affective state comes from reflection on situations encountered during design (Dong 2009)

Usually discussed towards the user (user-centred design) and targeting the audience (Koskinen et al., 2003). Studies on user-centred design discuss empathy as an important part of a design process, which can be influenced by individual ability and willingness (Kouprie and Visser 2009)

Some authors describe design as a "social ability" (Alexiou et al. 2009) i.e., a

"social process" more than a cognitive process, while taking into consideration that it is done by persons situated within a rich and dynamic social context and is not a mechanical process (Ball \& Ormerod, 2000a; Bucciarelli, 1988)

Refers to two main categories: task-focused i.e., those dealing with task accomplishment, and person-focused i.e., facilitation of team interaction and/or development (Burke et al. 2006)

The sense of personal responsibility for outcomes, which is more than a required qualification for industrial design work (Yang et al., 2005), it is also the designer's capacity to work within own beliefs

One of the most critical attributes for designers, directly impacting performance (Robinson et al., 2005)

A certainty in own abilities (Shanteau, 1988; Tracey \& Hutchinson, 2015) 


\begin{tabular}{|c|c|c|}
\hline & $\begin{array}{l}\text { Confidence in the } \\
\text { work }\end{array}$ & $\begin{array}{l}\text { A certainty in own professional skills (professional confidence) (Shanteau, 1988; } \\
\text { Tracey \& Hutchinson, 2015) }\end{array}$ \\
\hline & Cognitive abilities & $\begin{array}{l}\text { Understanding the design problem (e.g., Lawson, 2005), 'designerly thinking' } \\
\text { (e.g, Cross 1982; Oxman 1999), abstraction (e.g., Oxman, 1990), evaluation } \\
\text { /analysis (e.g., Khorshidi et al., 2016), and synthesis (Fiorineschi et al., 2016) }\end{array}$ \\
\hline & $\begin{array}{l}\text { Cognitive } \\
\text { strategies }\end{array}$ & $\begin{array}{l}\text { Learning through design (Elkjaer and Brandi 2014; Garner 2006), problem } \\
\text { framing (Cardoso et al., 2016; Cross, 2004), developing and evaluating a strategy } \\
\text { for conceptualisation (Fiorineschi et al., 2016; Kruger \& Cross, 2006), and } \\
\text { problem solving (Atuahene-Gima 2010; von der Weth 1999). }\end{array}$ \\
\hline & $\begin{array}{l}\text { Personal } \\
\text { communication }\end{array}$ & $\begin{array}{l}\text { The capacity to communicate clearly and directly, during the work process } \\
\text { through language and other representation (Robinson et al., 2005) }\end{array}$ \\
\hline & $\begin{array}{l}\text { Interpersonal } \\
\text { communication }\end{array}$ & $\begin{array}{l}\text { Awareness and management of communication capability, active management of } \\
\text { the team and colleagues (Crain et al., 1995; Sonnenwald, 1996) }\end{array}$ \\
\hline \multirow[t]{4}{*}{ DS } & $\begin{array}{l}\text { Education-based } \\
\text { knowledge }\end{array}$ & $\begin{array}{l}\text { Language competency (Bucciarelli, 2002; Dong, 2009), basic design knowledge } \\
\text { (McLaren and Stables 2008; Wilpert 2007), and focused subject knowledge } \\
\text { (Seitamaa-Hakkarainen and Hakkarainen 2001; Krawczyk and Murphy 2012) }\end{array}$ \\
\hline & $\begin{array}{l}\text { Practice-based } \\
\text { knowledge }\end{array}$ & $\begin{array}{l}\text { Negotiation capacity, imagination/representation quality and speed, IT } \\
\text { competencies, and knowledge appliance ability (Yang et al., 2005) }\end{array}$ \\
\hline & $\begin{array}{l}\text { Managerial } \\
\text { competency }\end{array}$ & $\begin{array}{l}\text { Managerial competency of generic tasks i.e., personal organisation and time } \\
\text { management, and a managerial competency for job-related tasks i.e., } \\
\text { accomplishment of deadlines and project milestones (Vaishya et al., 2016) }\end{array}$ \\
\hline & $\begin{array}{l}\text { Project } \\
\text { management }\end{array}$ & $\begin{array}{l}\text { Project planning, project development, and effectiveness assessment (Mir and } \\
\text { Pinnington 2014; Coates et al. 2004). The ability to plan a project stresses a basic } \\
\text { structure in design work (Yang et al., 2005), especially in consultancy (Hakatie } \\
\text { and Ryynänen 2007), through which the client's views and the designer decisions } \\
\text { are aligned to produce satisfactory outcomes for both (Lewis and Bonollo 2002) }\end{array}$ \\
\hline
\end{tabular}

\section{Sample}

Thirty-five semi-structured interviews were conducted: professional designers with 10 to 15 years of experience $(\mathrm{N}=10)$, professors with 16 to 20 years of experience $(\mathrm{N}=16)$, and managers with 9 to 25 years of experience $(\mathrm{N}=9)$. All subjects were permanent residents of Denmark and had connections to the Design and Innovation programme offered at the Technical University of Denmark. The professors lectured in a formal design engineering education. The managers and designers were drawn from nine companies, ranging from large to small, consultancy to product developer. The range of products produced by the companies varied from highly technical to highly user focused, providing a cross section of design related industries. This gave an overview of major engineering design work in Denmark and thus provides a good basis for discussing DPI. 


\section{Data Collection}

To address the multiple elements in DPI a multi-faceted methodology was adopted based on the recommendations of Wenzel and Kraiger (1997). Thus, the interview procedure consisted of three steps:

(1) A semi structured interview with open-ended questions to let the interviewees reflect on the role and main characteristics of a designer. The interview started with general questions about the roles and responsibilities of designers and moved towards specific questions about the interviewee's perspective on the DPI elements in relation the role of a designer (see Appendix for the questions). The questions were designed by the authors to lead interviewees through a number of perspectives on DPI derived from literature i.e. roles and characteristics, most/least important characteristics, and link between characteristics and competence.

(2) A questionnaire that allowed interviewees to attribute importance to sentences describing design activities and design knowledge, correlated to the DPI elements (see Appendix for the questions). The questionnaire items are the DPI elements as derived from literature. Knowing the importance an interviewee assigns to a DPI element provided a deeper understanding of the aspects mentioned in Step 1, as well as a knowledge on the perceived core elements.

(3) A concept mapping exercise that allowed interviewees to allocate the DPI elements to a generic NPD process (see Appendix for an example). The interviewees were provided with a basic template but were free to use this (or not) as well as any other resource to explain their points of view (including drawing and repetition of elements along the process). They were asked which characteristics they believed were required, or not, for a designer during NPD. 
The open-ended questions were discussed before any other materials were provided to the interviewees to avoid priming. During Steps 2 and 3, 'think aloud' was also used to provide extra qualitative insights.

\section{Data analysis}

The 35 semi-structured interviews (Step 1) were transcribed and analysed qualitatively. Transcription was accomplished using the Dragon software with subsequent manual correction. Based on these transcriptions, thematic analysis was carried out following an iterative process between the first two authors. First, the qualitative data from the individual interviews was systematically analysed via inductive coding (Miles and Huberman 1994; Blessing and Chakrabarti 2009). This 'first pass' of deriving qualitative themes was carried out via three workshops. Here the first two authors gradually derived and refined categories and concepts in the transcribed data pertaining to the main research questions via iterative coding cycles until a final set of codes had been developed (Patton 2001). Second, these codes were further iteratively refined by specifically contrasting the data within each group of interviewees (designers, professors and managers). Again, this was carried out via three workshops between the first and second author until all discrepancies in code interpretation had been eliminated and all evidence could be allocated (compare Patton 2001). Third, this coding was used as the bases for a systematic 'second pass' cross-interview analysis, which identified and refined key themes using axial coding i.e. relating categories and concepts via a combination of inductive and deductive analysis with a focus on making coded concepts more abstract. This was followed by selective coding that focused on strengthening the understanding of the themes by describing critical exemplars for each (Neuman 1997; Patton 2001). This process resulted in three major themes that draw together insights from across data sources and offer consistent explanatory power across the interviews 
(RQ1). As such, analysis followed standard best practice for deriving comparative insights from a small sample of in depth interviews with mixed methods data (Christensen, Johnson, \& Turner, 2011, p. 363; Neuman, 1997, p. 511).

Analysis of the questionnaire responses and concept mapping was subsequently used to detail the themes with respect to the prioritisation of DPI elements, and their relative importance with respect to the NPD process (RQ2). Descriptive statistics were derived from the survey items (see Appendix). For the concept mapping step, following Ulrich and Eppinger (2003), we proposed a generic NPD process, consisting of five phases: definition, ideation, development, validation and product delivery or launch. The respondents were asked to allocate DPI elements to NPD phases, based on the importance of each element in the specific phase. Evaluation of the results for all three groups produced a network of DPI element allocation over these phases. Analysis of this data used shared mental models techniques of Neumann (2012) and others. Concept maps are representations of the relations that people perceive among elements, in this case, the relations between the DPI elements and the phases of NPD. Neumann (2012) (p.29-31) describes three main indicators that determine how much the concept maps produced by the different groups are aligned. These indicators are sharedness (CannonBowers and Salas 2001), accuracy (Rentsch and Hall 1994) and importance of a mental model. We applied all three in this study. Sharedness takes account of concepts that are both shared among (i.e., overlapping or identical) and shared between (i.e., complementary) (Klimoski and Mohammed 1994). Accurate concept maps tend to be shared among the group (Badke-Schaub et al. 2007). Importance can be assessed on two levels: attributed importance (taking account of the questionnaire) and centrality (based on the number of the network connections) (Badke-Schaub et al. 2007). As such, 
comparison between the groups provides additional understanding of DPI expectations during NPD.

\section{Results}

The thematic analysis of the open-ended interviews identified three major themes: (1) Technique, (2) Creativity, and (3) Rapport. Technique refers to designer practice, DS, methods or technical abilities. Creativity refers to designers' brilliance, mind-set, creativity, intentions or multidisciplinary capacity. Rapport refers to designers' empathy, communication, collaboration or interaction abilities. These themes are elaborated below in relation to the research questions.

\section{Social- and self-perceptions regarding designer's role and expected characteristics (RQ1)}

Interviewees in all groups identified aspects related to the three themes: Technique (T), Creativity $(C)$ and Rapport $(R)$, while each group emphasised one. Throughout, quotes are associated with their respective source: designers (D)1-11, professors (P)1-15, and managers (M)1-6, as well as the open-ended questions that elicited them (see Appendix). First, designers tended to emphasise aspects related to Technique, and saw themselves as practical and creative 'doers'. They saw their role as bringing an idea from concept to production -making use of their knowledge and methods. This group saw their role as "being able to make radical changes to an already available product and see one's design being brought into the production, to bring it to the next level" (D5 Q1). Designers saw their main ability as the use of methods and managing projects in order to deliver "something practical and meaningful" (D2 Q1). However, they also believed: "I think the designer is not only a problem solver. The role of a designer is to come up with unexpected things" (D1 Q1). While many interviewees highlighted this 
role, none attributed this characteristic to their actual role in the company. Typically, it was perceived that firms expect designers to be pragmatic: "in our company [...] we decide products for our clients. That's almost all that we do" (D3 Q1). In addition, in terms of efficacy, they have "to be able to handle the whole project, from idea to making it come true" (D5 Q1). Idiosyncratic responses highlighted the role of the designer at two extremes, as a visionary verses method implementer: [the designer] "is to be visionary, because within an organisation there will always be people who are working on the incremental efficiency of the product - to increase the performance of the product or make production easier - or satisfy the needs of the user incrementally" (D5 Q1). However, at the same time, the designers highlight their reliance on a structured way of thinking: "for me, it's a way of thinking, a method. The way that I perceive a task from when I get it to how to solve it" (D4 Q1). Thus, designers have to do more than solve the problems; they must be able to make use of methods and carry the process to its end while adding value and satisfying user needs.

Second, design professors generally emphasised aspects related to Creativity, and a view of the designer as an innovative, creative thinker. They focused on designerly thinking i.e., having a design mind-set, ability to question the situation and challenge the status quo creatively, as well as to take an idea from concept to embodiment, based on skills and knowledge. This requires the designer to have the ability to work in a multidisciplinary setting. As explained by the professors, "the designer is someone who bridges all these disciplines together" (P3 Q1), thus "their role is to put different elements together in order to standardise the creative process" (P4 Q1). The professors generally concluded that their main focus when teaching was not just to provide the basic technical knowledge but to create a questioning and creative mindset: "I think the mind-set is what creates the designer [...] I am very 
aware, when I plan my classes that this lecture is about creating a mind-set..." (P1 Q3). Further, professors attributed making radical changes or finding unexpected solutions as fundamental to the designer's role. Designers have to pursue knowledge, skills, and attitudes towards creating new solutions and providing changes. "Designers are, in my eyes, change agents. They create the surrounding around us and for that they need to be agile [mentally]" (P3 Q3). Professors perceived designers as contributing to society "by improving the environment at all stages, in production, the working environment, the use of resources, water, energy and so on. And then the way their product impacts during use, recycling and end of life" (P5 Q2).

Finally, managers tended to emphasise aspects related to Rapport and focused on the designer in terms of satisfying clients. They saw the designer as a bridge between the company and its clients, i.e., to "find out what is good for the company and for the customer” (M3 Q1) and then implement the technical aspects in a solution. They felt the designer should "help to develop visions among our clients, of how they can perform better with whatever they are doing and then translate it into some kind of engineering work, some technical stuff" (M2 Q1). At the same time, as professionals, designers should be able to create novelty and make fast decisions based on their knowledge: "One of the fundamental things is that they have the right background, that they know their skills, and they can take some decisions based on what they know" (M1 Q1). None of the managers attributed radical changes or unexpected solutions to the role of a designer in a company; focusing instead on the designer having to solve the client's problem and effectively facilitate the process: "you have a responsibility as a designer to try to make things better not only for you but also for other people" (M5 Q2). Thus, "you have to be good at your professional skills, but it is also very important that you are able to listen to the others in the group and interact with them, and 
understand their [the clients'] problems and find the best solution” (M1 Q3). The relation between technical ability and precise communication, empathically addressing the client's needs, are reflected in positive outcomes according to the managers, i.e., "If I can show the path to the new concept in a logical and convincing way, then I have the customers' right where I want them and I probably also have a very good product" (M4 Q3). Individual responses focused on performance and the work environment. For example, as a designer "you have to be good at your skills, but it is more important that you are good at cooperating, can do your job quickly and you are dynamic - when things go wrong we have to find a solution very quickly. Being a good team player helps everyone " (M1 Q2). Thus, managers saw the designer's role as more than finding solutions to clients' problems; they saw it as important not to create problems at work and to be able to efficiently manage the project.

Overall perceptions regarding the designer's role and identity differed across the groups, particularly with respect to the expected characteristics in each context, i.e., the educational and professional environment. Differences concerning social attributions and characteristics were expressed in relation to the Creativity and Rapport themes, while designers' self-perception and expectations emphasised the need for a technically reliable outcome at the end of the project, and stressed design through Technique. These thematic differences are also reflected in how each group ranked the elements of an ideal designer, and their importance during NPD.

\section{Differences in social- and self-perception regarding attributions of importance for DPI elements (RQ2i)}

Perception of DPI relies on understanding the designer as a professional based on his or her role. Thus, the attribution of PA and DS elements was analysed in relation to perception of a good designer, as summarised in Figure 1. Here, designers highlighted 
elements related to Technique: Knowledge from Education (+EK), Knowledge gained through Practice (+PK), Cognitive Abilities (+CA), Cognitive Strategies (+CS), Communication of ideas (+PC), and Project Management $(+\mathrm{PM})$. Figure 1 treats the designers self-perception as the 'zero' baseline, against which differences are highlighted. Professors focused on PA elements along with knowledge from education related to Creativity: Motivation ( $+\mathrm{MO})$ in terms of 'being curious' (drawn from the think aloud data); Responsibility (+RE) in terms of determination and perseverance; Emotions (+EM) in terms of being stable and resilient to failure - seeing failure as learning; Empathy $(+\mathrm{EP})$ and Confidence $(+\mathrm{CO})$ in terms of being humble and curious about people - listening and understanding the context; and Creativity $(+\mathrm{CR})$ and Openness $(+\mathrm{OP})$ in terms of discovering new approaches and solutions - digging down into unexpected new areas. Managers focused on elements linked to Rapport, that facilitate socialisation such as Social Abilities (+SA), Empathy (+EP), Openness (+OP), and Interpersonal Communication' (+IC). Moreover, they emphasised Manager Competency $(+\mathrm{MC})$, Creativity $(+\mathrm{CR})$, and Motivation $(+\mathrm{MO})$.

The key differences between the groups are highlighted in Figure 1, and fall into three general types: a) managers and professors provide contrasting views and differ from designers; b) managers and professors agree, but differ from designers; and c) either professors or managers agree with designers and only one group is different from the other two. Descriptive statistics are provided in the Appendix. A non-parametric Mann-Whitney U test was carried out on the various comparisons between groups. However, as expected with such a small sample size, statistical analysis was not significant except, marginally, with respect to Responsibility (RE) where differences were most pronounced (designers $\mathrm{v}$. professors $\mathrm{p}=0.0854$, designers $\mathrm{v}$. managers $\mathrm{p}=$ 0.0524). As the purpose of this study was to develop analytical generalisability via a 
combination of qualitative analyses - not to develop statistical generalisability across all designers - these results do not affect the qualitative robustness of the work (Robson and McCartan 2011, 154). Rather, they point to the potential for larger sample surveys to examine the statistical generalisability of the findings.

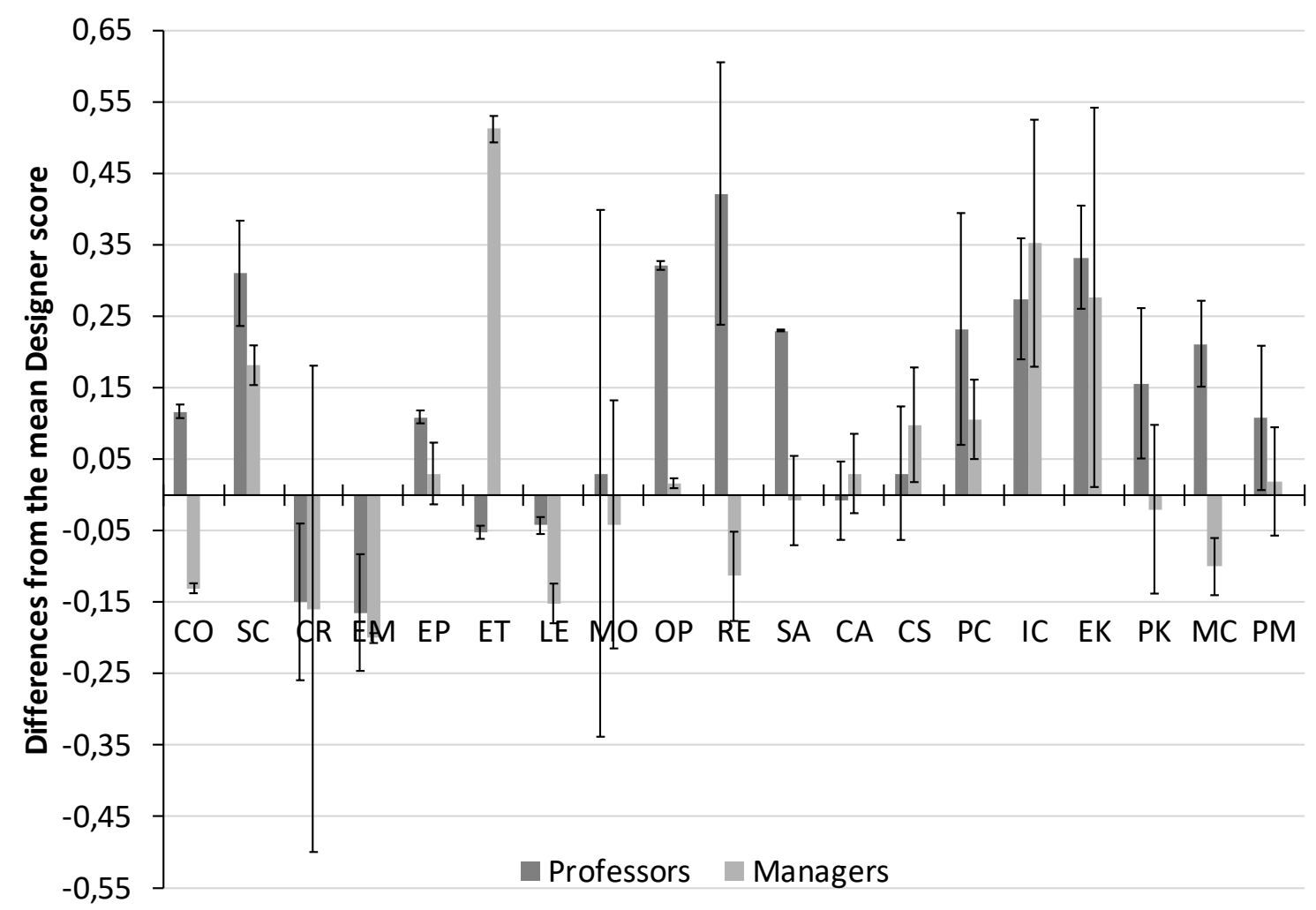

Figure 1. Differences in attributions of importance for DPI elements in comparison to the designer mean 'zero'. Note: negative results reflect higher prioritisation

Differences following the first type include Confidence (CO), Ethics (ET), Responsibility (RE) and Managerial Competencies (MC). Managers prioritised Responsibility (RE) compared to designers (-0.11), while professors considered it less important (0.42), with the two groups are substantially different (-0.54). Similarly, Confidence $(\mathrm{CO})(\mathrm{P}=0.12 ; \mathrm{M}=-0.13 ; \mathrm{P}-\mathrm{M}=-0.25)$, and $\mathrm{MC}(\mathrm{P}=0.21 ; \mathrm{M}=-0.10 ; \mathrm{P}-\mathrm{M}=-$ 0.31), all display differences in opposite directions with managers attributing more importance to these elements than designers, and professors attributing less. For Ethics (ET) professors attribute slightly more importance than designers, while managers 
consider it to be much less important $(\mathrm{P}=-0.05 ; \mathrm{M}=0.51 ; \mathrm{P}-\mathrm{M}=0.56)$.

Following the second type, professors and managers attribute more importance to Creativity (CR), Emotions (EM) and Leadership (LE). However, designers attribute more importance than professors and managers to Self-Confidence (SC), Empathy (EP), Personal Communication (PC), Interpersonal Communication (IC) and Knowledge from Education (EK). In particular, designers prioritised Self-Confidence (SC) compared to both managers $(0.18)$ and professors $(0.31)$, Interpersonal Communication IC $(\mathrm{P}=0.27$; $\mathrm{M}=0.35 ; \mathrm{P}-\mathrm{M}=0.08)$ and Education $(\mathrm{EK})(\mathrm{P}=0.33 ; \mathrm{M}=0.28 ; \mathrm{P}-\mathrm{M}=-0.06)$.

Following the third type, designers and managers share perceptions of Openness (OP) $(\mathrm{P}=0.32 ; \mathrm{M}=0.02 ; \mathrm{P}-\mathrm{M}=-0.30)$, Social Abilities (SA) $(\mathrm{P}=0.23 ; \mathrm{M}=-0.01 ; \mathrm{P}-\mathrm{M}=-$ 0.24), Knowledge from Practice ( $\mathrm{PK})(\mathrm{P}=0.16 ; \mathrm{M}=-0.02 ; \mathrm{P}-\mathrm{M}=-0.18)$, and Project Management $(\mathrm{PM})(\mathrm{P}=0.11 ; \mathrm{M}=-0.02 ; \mathrm{P}-\mathrm{M}=-0.09)$ while professors attribute less importance to these elements. These different prioritisations are summarised in rankings in Figure 2. The rank calculations are provided in the Appendix.

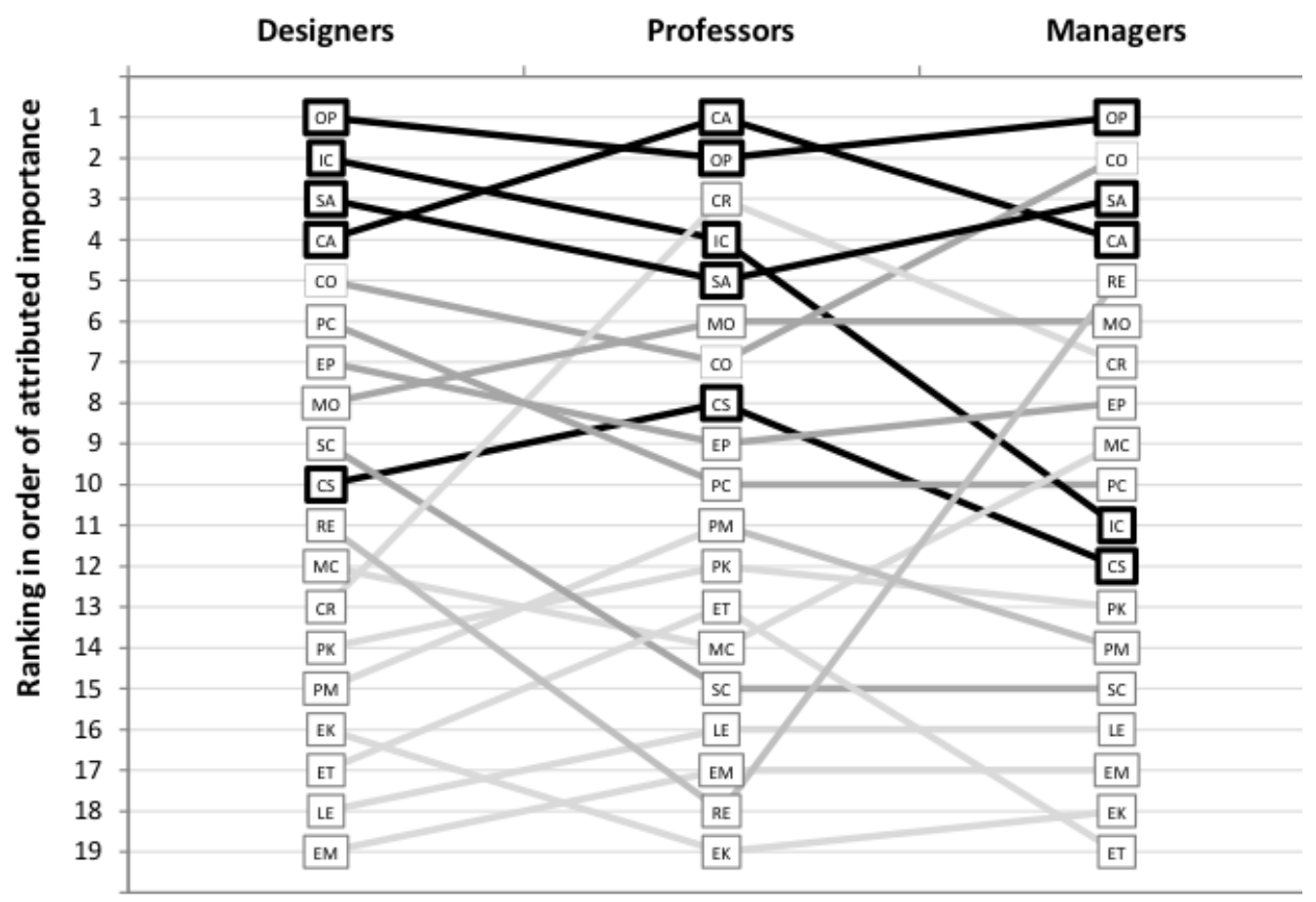

Figure 2. Comparison of DPI elements' rankings based on mean scores for importance attributed by each group 


\section{Differences in social-and self-perceptions regarding the allocation of DPI elements in relation to NPD (RQ2ii)}

Finally, in relation to NPD, the three groups show a number of differences based the concept maps, as depicted in Figure 3 and Table 3. A complete table of expressed sharedness (\%) among the respondents is provided in the Appendix. Figure 3 shows the relative distribution of focus in the different groups based in the strength (indicated by line shading) and number of connections to the various phases of the NPD process. For example, the development phase has a large number of strong connections making it central to the managers' concept map (Figure 3b); suggesting a focus on this phase from their perspective. Contrast this with the distributed connections across the various NPD phases in the designers' concept map, indicating lower centrality and a distribution of focus across the process (Figure 3a). In general, designers indicated a need for most of the elements across all NPD phases, as shown by the balanced network in Figure 3a. This 'whole project' view supports the thematic focus of designers as practicallyoriented creative doers, responsible for developing the design from the start of the project to production. In the early phases Cognitive Abilities (CA)/Strategies (CS), Empathy (EP), and Creativity (CR) were important, in the middle Confidence (CO) and Leadership (LE), and at the end Managerial Competency (MC) and Interpersonal Communication (IC).

In contrast, professors focused on the early phases of NPD, as shown in Figure 3c. This is linked to their view of the designer as a creative thinker who promotes innovation. They highlighted Creativity (CR) and Knowledge from Education (EK) during the ideation phase, as well as Confidence $(\mathrm{CO})$ at the end of ideation, to kickstart a healthy development phase. Further, managers emphasised Managerial Competency (MC) and Social Abilities (SA) as important during the whole of NPD. 
This is linked to their pragmatic view of the designer as the interface between client and firm. However, managers focused mainly on the middle phases as shown in Figure $3 b$. Thus, in the managers view, during validation, self-confidence and ethics (towards users) are important for the problem-solving process and delivery is mainly an administrative task that does not require specific designer attributes. Similar to the results in Figure 1, the three groups differed in the priority given to different phases of NPD. 


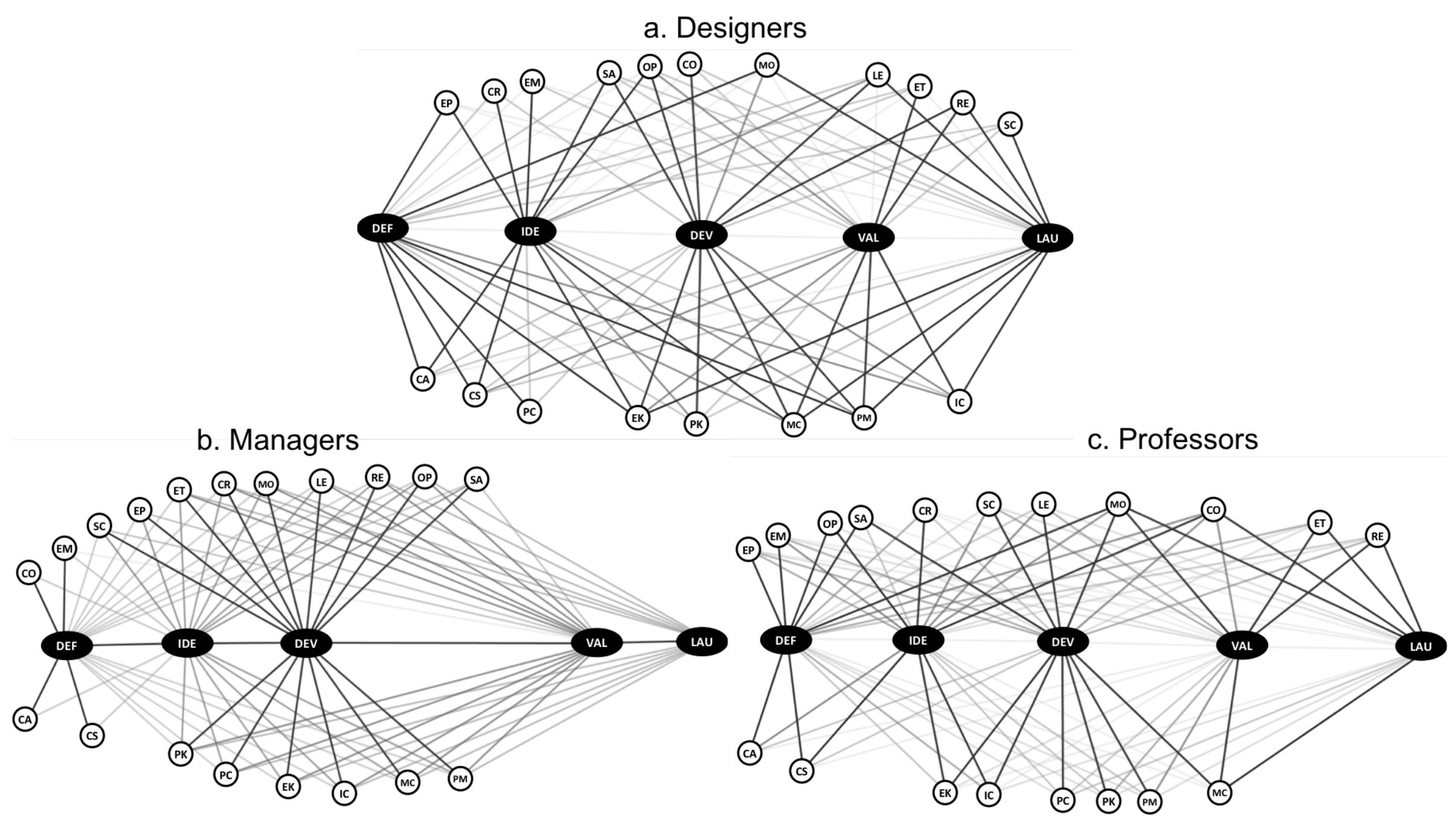

Figure 3. DPI elements across NPD and perception sharedness (DEF: definition, IDE: ideation, DEV: development, VAL: validation, LAU: launch) 
Table 3. Percentage of respondents agreeing with allocation of DPI elements across NPD

\begin{tabular}{|c|c|c|c|c|c|c|}
\hline & & Definition & Ideation & Development & Validation & Launch \\
\hline \multirow{2}{*}{ 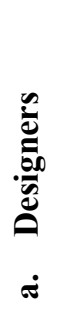 } & PA & $\begin{array}{c}\text { EP }(57 \%) \\
\text { MO (57\%) }\end{array}$ & $\begin{array}{c}\text { CR }(100 \%) \\
\text { EP }(71 \%) \\
\text { OP }(71 \%)\end{array}$ & $\begin{array}{c}\text { CO }(100 \%) \\
\text { LE }(71 \%) \\
\text { OP }(57 \%)\end{array}$ & $\begin{array}{l}\text { ET }(43 \%) \\
\operatorname{RE}(43 \%) \\
\text { OP }(43 \%)\end{array}$ & $\begin{array}{l}\text { RE (57\%) } \\
\operatorname{LE}(43 \%) \\
\operatorname{MO}(43 \%) \\
\operatorname{SC}(43 \%)\end{array}$ \\
\hline & DS & $\begin{array}{l}\text { CS }(86 \%) \\
\text { PM }(86 \%) \\
\text { CA }(71 \%) \\
\text { PC }(71 \%) \\
\end{array}$ & $\begin{array}{l}\mathrm{CS}(86 \%) \\
\mathrm{EK}(71 \%) \\
\mathrm{CA}(71 \%)\end{array}$ & $\begin{array}{l}\text { EK }(86 \%) \\
\text { MC }(86 \%) \\
\text { PM }(71 \%)\end{array}$ & $\begin{array}{c}\text { PM }(86 \%) \\
\text { MC (57\%) } \\
\text { IC (57\%) }\end{array}$ & $\begin{array}{l}\operatorname{IC}(43 \%) \\
\operatorname{EK}(43 \%) \\
\operatorname{MC}(43 \%) \\
\operatorname{PC}(43 \%)\end{array}$ \\
\hline \multirow{2}{*}{ 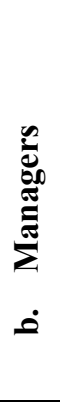 } & PA & $\begin{array}{c}\text { CO }(75 \%) \\
\text { CR }(75 \%) \\
\text { EP }(75 \%) \\
\text { MO }(75 \%) \\
\text { SA }(75 \%)\end{array}$ & $\begin{array}{l}\text { CR }(75 \%) \\
\operatorname{EM}(75 \%) \\
\operatorname{EP}(50 \%) \\
\operatorname{LE}(50 \%) \\
\operatorname{SA}(50 \%)\end{array}$ & $\begin{array}{l}\text { RE }(75 \%) \\
\text { CR }(50 \%) \\
\text { LE }(50 \%) \\
\text { MO }(50 \%) \\
\text { SA }(50 \%)\end{array}$ & $\begin{array}{l}\text { SC }(50 \%) \\
\operatorname{ET}(50 \%) \\
\operatorname{MO}(50 \%) \\
\operatorname{RE}(50 \%) \\
\text { SA }(50 \%)\end{array}$ & - \\
\hline & DS & $\begin{array}{c}\mathrm{CS}(75 \%) \\
\mathrm{EK}(75 \%) \\
\operatorname{MC}(75 \%)\end{array}$ & $\begin{array}{l}\text { IC }(75 \%) \\
\text { PK }(75 \%) \\
\text { MC }(75 \%) \\
\text { PM }(75 \%)\end{array}$ & $\begin{array}{l}\text { IC }(75 \%) \\
\text { PK }(75 \%) \\
\text { MC }(75 \%) \\
\text { PM }(75 \%)\end{array}$ & $\begin{array}{l}\text { MC (75\%) } \\
\text { PM }(75 \%) \\
\text { PC }(50 \%) \\
\text { IC }(50 \%) \\
\text { PK }(50 \%) \\
\end{array}$ & $\begin{array}{l}\text { PK }(50 \%) \\
\mathrm{MC}(50 \%)\end{array}$ \\
\hline \multirow{2}{*}{ 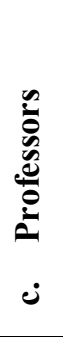 } & PA & $\begin{array}{c}\text { EM }(70 \%) \\
\text { EP }(70 \%) \\
\text { OP }(70 \%) \\
\text { CR }(100 \%)\end{array}$ & $\begin{array}{l}\text { OP }(80 \%) \\
\text { CO }(60 \%) \\
\text { LE }(70 \%) \\
\text { SC }(60 \%)\end{array}$ & $\begin{array}{l}\text { MO }(60 \%) \\
\text { RE }(80 \%) \\
\text { MO }(60 \%)\end{array}$ & $\begin{array}{l}\text { ET }(50 \%) \\
\text { CO }(50 \%) \\
\text { CO }(40 \%)\end{array}$ & $\begin{array}{c}\text { ET }(40 \%) \\
\text { MO }(40 \%) \\
\text { RE }(40 \%)\end{array}$ \\
\hline & DS & $\begin{array}{l}\mathrm{CA}(80 \%) \\
\mathrm{CS}(70 \%) \\
\mathrm{IC}(40 \%)\end{array}$ & $\begin{array}{c}\text { CS }(80 \%) \\
\text { CA }(50 \%) \\
\operatorname{IC~}(50 \%) \\
\operatorname{EK~}(50 \%)\end{array}$ & $\begin{array}{l}\mathrm{MC}(90 \%) \\
\mathrm{PM}(90 \%) \\
\mathrm{PK}(60 \%)\end{array}$ & $\begin{array}{l}\mathrm{MC}(70 \%) \\
\mathrm{PM}(50 \%) \\
\text { PK }(40 \%)\end{array}$ & $\mathrm{MC}(40 \%)$ \\
\hline
\end{tabular}




\section{Discussion}

This study set out to understand the social- and self-perceptions regarding the designer's role and DPI elements (RQ1), as well as differences in perception between designers, professors, and managers (RQ2). We answer RQ1 by describing three distinct themes: Technique, Creativity and Rapport, which we then contrast in order to answer RQ2. The findings highlight critical differences in the perceptions of the three groups: designers, professors and managers, with implications for managing the transition from student to professional designer (Lichtenstein et al., 2009).

Across all the interviewed designers, the role of the designer as a problem-solver was linked to a practice-oriented approach under the theme Technique. This corresponded to a focus on seeing the project as a process, from idea to production and successful delivery (Figure 3). Overall, designers see their role as involving exploitation of their knowledge, often in the form of methods, to manage the project through all its phases and fulfilment of user/client needs. This aligns with literature, which highlights design as much more than problem solving (Bucciarelli 1988). This view is aligned with one of the five types of learning path proposed by Poell \& Van Der Krogt (2014), where the focus is on improving every-day work processes. By adapting the knowledge gained from formal education to professional work practice, and by experimenting with behaviours to achieve success, designers make dynamic amendments to their professional identities (Ibarra 1999).

This view differs from the perception of design professors who focused on the theme of Creativity. Professors considered aspects of professionalism to be inspirational characteristics. In contrast to managers, professors saw the designer's role as questioning and challenging the state of the art, and proposing creative solutions. Professors focused on a contribution-oriented approach that acknowledges the creative 
potential of designers as key to meaningful change, especially in the early phases of NPD. Barnett (2011) highlights that universities aim to teach theoretical and formal knowledge, but need, also, to prepare students for the world of work. This contributionoriented approach is aligned with much of the design education literature (see e.g., Bonsiepe 1994). For example Haase (2014) investigates PI elements in a sample of more than 3,000 Danish engineering students, and found that creating things, i.e., being inventive and creative, was the most common characterisation among over $40 \%$ of respondents.

Finally, managers' perceptions linked to a client-oriented approach under the theme Rapport; and differed from both designers and professors. This refers to an orientation towards communication with and satisfaction of clients. Managers emphasised client focused empathy, responsiveness and cooperation. This is in line with Sun et al. (2011), who describe managers as responsible for ensuring successful delivery of a design output matching the company's strategy and the client's expectation. This also links to the challenges highlighted by Hakatie \& Ryynänen (2007) in relation to industrial design consultancy, where management and design practices have to adapt to market competition. Here, a "flawless" bid is based on an extremely high level of knowledge, and a good understanding of the client's processes and problems (Hakatie and Ryynänen 2007).

These findings highlight a critical issue associated with a lack of alignment between the educational and professional environments. While Littlejohn (2011) notes that each of the professors she interviewed considered it necessary to prepare students for their career by distancing design from the 'creative genius' model, we found that creativity was a primary focus for professors and was reflected in the students' perceptions in line with the work of Haase (2014). In contrast, the perspective of 
managers was distinctly different, and focused on promoting designers' autonomy in self-management and decision-making, as well as confidence and social relations at work. This throws light on critical changes in perception that designers have to face in the transition from educational to professional environments. This transition reflects a shift in social-perception, from the professors' to the managers' point of view, respectively emphasising the early and late phase responsibilities of the designer. Ibarra (1999) highlights that the process of constructing a PI is congruent with self-conception as a professional. Thus, it is perhaps unsurprising that designers, themselves, expressed a mix of self-reflections and expectations about professionalism, which differed from the perceptions of both professors and managers. While these results are congruent with general studies on PI, the comparisons reported here highlight the need for a better alignment between education and practice in design, and greater support for specific DPI elements with substantial differences across these contexts.

\section{Contrasting social-perceptions and self-perception of designers and implications for DPI development}

The changing perspectives between educational and professional environments related to social- and self-perceptions contribute to shaping PI (Trede 2012b; Cohen-Scali 2003). While the general challenge associated with differences between education and practice has been described (Dall'Alba 2009; Etela 2000; Littlejohn 2011), the results of this study highlight a number of differences particularly critical to DPI. Specifically, professors and managers prioritise substantially different DPI elements, most notably creativity during early phase NPD verses responsibility during NPD development (Figure 3). Contrasting further, designers identify themselves as somewhere between these two extremes, neither prioritising creativity or responsibility nor early or midphase NPD (Figure 3), but rather highlighting elements such as Confidence and 
Empathy across the whole NPD process. These detailed insights extend prior comparisons of education and practice, which have typically described overall development of expertise (Smith 2015) and competency (Helfat and Martin 2015), or focused on specific DPI elements in isolation, such as confidence (Zhang 2015) or uncertainty and reflection (Tracey and Hutchinson 2016). Further, no prior works, to the authors' knowledge, have evaluated how differences in perspective on DPI vary across the phases of the NPD process. As such, this work provides an important contribution in the form of a detailed comparison across the range of elements comprising DPI. The major differences found in our work are illustrated in Figure 4.

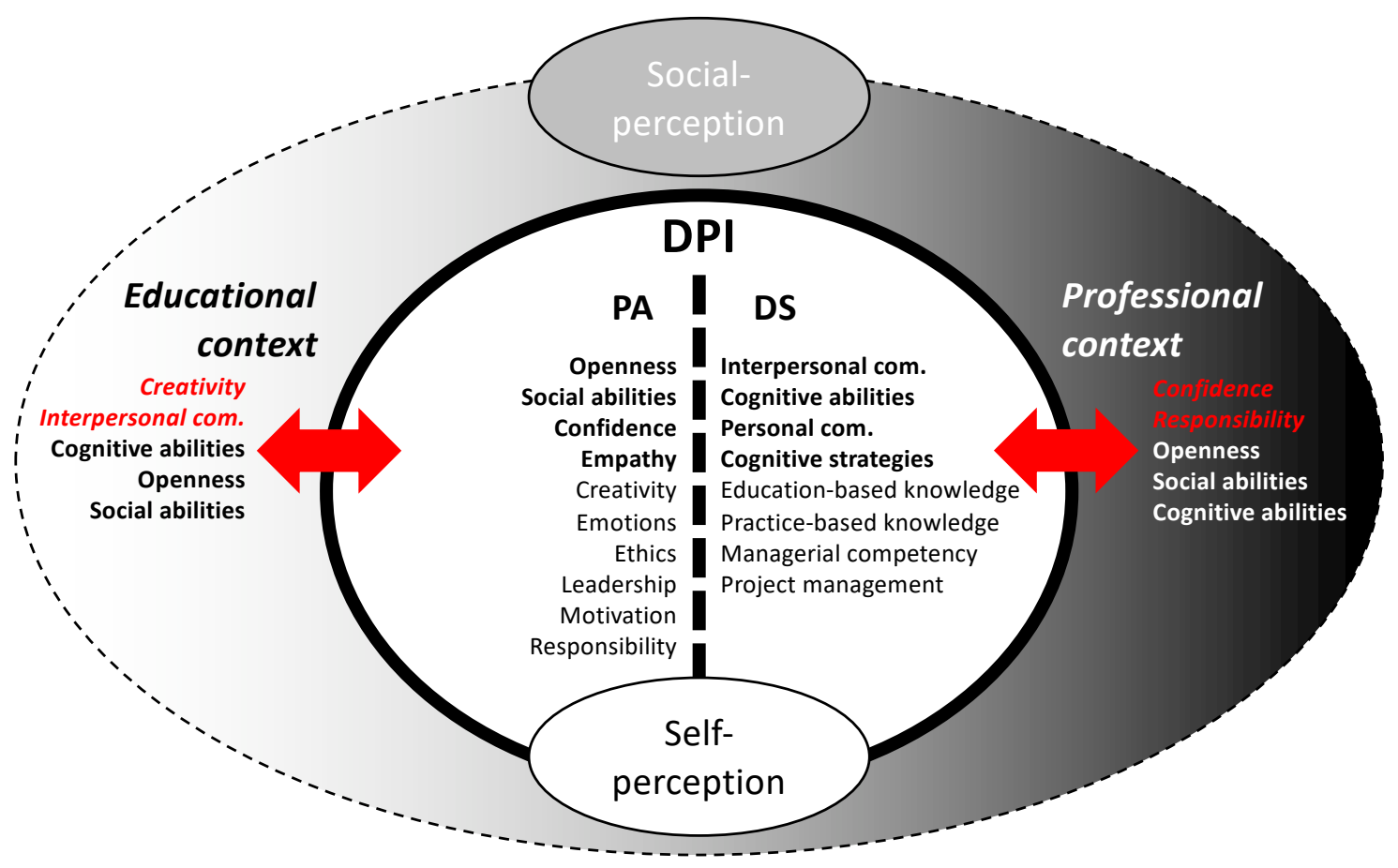

Figure 4. Differences in self- and social-perception of DPI

Figure 4 shows how designers adopt a third approach to the professional role and DPI elements, compared to professors and managers. This 'mid-point' perspective held by designers in our study logically corresponds to their progression from the educational to professional context, and the differing social-perceptions these represent. This aligns with prior research on how DPI develops over time, via a general adaption of the self to 
the professional environment to balance social-perception of role-models (Ibarra 1999). In particular, Grace \& Trede (2013) conclude that formal education in the classroom and informal learning during professional placements were equally important for the development of student's sense of professionalism. Thus, the specific differences highlighted in Figure 4 have significant implications for this adaption process.

Prior research has shown that changes in social-perceptions force a partial deconstruction of expectations built during education in order to adapt to and pursue a career (Tynjälä \& Newton 2014). In our study, one designer succinctly highlighted this difficulty as: "sometimes I see it [the role of a designer] more as a method but when I talk to people about developing a product or something with more aesthetics I see how it lights in their eyes. I see that is what they think a designer is. And then, all of a sudden, I see myself more as that kind of designer" (D4). This period of transition has been found to take up to three years (Dahlgren et al., 2014), with the associated challenges in professional identification reflected in poor work performance (Adams et al., 2011), mental health (De Goede et al., 1999) and drop-out (Khapova et al., 2007; Worthington et al., 2013). Thus, understanding the specific differences in perceptions of professors and managers directly contributes to understanding and potentially mitigating these issues.

\section{Implications, limitations and further work}

In addition to the theoretical contribution discussed above, this work has practical implications for education and practice. First, the substantial misalignment between the professors, managers, and designers - even in the closely related sample used in this study - highlights the need for further efforts to address design education towards the perceived DPI of actual designers. Several studies argue that careful management of identity formation during education can enable students to better adapt to the challenges 
of the field (Evetts 2003; Tracey and Hutchinson 2013) and to identify those elements of practice that should be retained and those that can or should be transformed (Trede 2012a). Further, despite a focus on development of competencies and skills, the educational environment provides enough space for both formal learning and professional practice (Trede 2012a). In particular, the educational programme included in this study already has extensive industry interaction, thus more deliberate management of this interaction with respect to DPI is likely desirable e.g. focusing specifically on those elements that change substantially.

Second, managers should be aware of the differences in their prioritisation of DPI elements and NPD phase, and the potentially serious issues this can cause designers. More specifically, the detailed results of this work highlight how managers could target support towards helping designers adjust to the increased focus on responsibility and customer orientation, the decreased focus on creativity, and the need to balance attention across the NPD process. Generally, our research highlights the importance of fostering awareness of DPI amongst design managers.

Tempering these implications, this study has two main limitations. First, we focused on evaluating differences between social- and self-perceptions specifically with respect to the perceptions of professors and managers in comparison to designers. While professors and managers have been shown to be major arbiters of social-perception in the educational and professional contexts (Hasse 2014; Sun 2011; Baumeister and Muraven 1996), peers also play an important role in DPI development. However, we do not evaluate differences within the designer 'peer group' in this study. This is because within group differences are generally less pronounced and require a different approach to their investigation, more akin to studies of design expertise (Ball and Ormerod 2000). This was also found in our study, where no within group differences approached the 
significance of the differences found between groups. Thus, while the results of this study are qualitatively robust and provide an important insight into differences in perception between groups, further work is needed to longitudinally investigate differences within the peer group of designers.

Second, this study focused on a sample of professors, managers and designers in Denmark. This was selected due to the fact that within Denmark all three groups were directly linked via a single educational programme. This provided an ideal basis for investigating contrasts in perspectives, whilst mitigating other potentially confounding factors, such as radically different educational backgrounds. Thus, the results provide qualitatively robust theoretical insight, but importantly, cannot be considered statistically generalisable. Further work is needed to more broadly investigate how the differences highlighted in this study translate to other countries and design education contexts.

\section{Conclusions}

This paper examined how social- and self-perceptions of the designer's role and identity differ between designers, design professors and design managers. We close this gap by answering the following research questions: What are the social- and self-perceptions regarding the designer's role and the Designers' Professional Identify (DPI) elements? What are the differences in the perceptions of professors and managers in comparison to designers with respect to i) overall importance of DPI elements, and ii) their relative importance at different phases during the NPD process? Critically, we found that the three groups had substantially different views on DPI. Specifically, designers reported a practice-oriented view where the focus is on a successful outcome (product or service) at the end of the design process. Designers attributed importance to elements related to the need for a technically reliable project outcome, focusing on achieving a creatively 
satisfying result that responded to user needs through an efficient process. In contrast, professors adopted a contribution-oriented view with a strong focus on the creative and innovative capability of the designer, while, managers took a client-oriented view with an emphasis on the designer's ability to be empathic and establish agreement with colleagues and clients. We draw these themes together as: Technique, Creativity and Rapport focused conceptions of DPI. As such, we extend understanding of professional identity in design, and highlight the potentially conflicting views held by major stakeholders in a designer's development. Importantly, the lack of observed alignment between the three groups highlights a significant practical challenge for design professionals, educators and managers. Specifically, professors and managers both contribute to DPI development and changes in perspective can make the transition from educational to professional environment difficult. As such, this research highlights the need for better alignment between education and practice, and support for designers during the transition between these contexts.

\section{Acknowledgements}

The authors would like to thank the reviewers and editor for their constructive comments, that have helped develop this work. The authors are also grateful to the National Council for Scientific and Technological Development (CNPq)/Brazil that has sponsored the first author via Ph.D. scholarship (201719/2014-2).

\section{References}

Adams, R S, S R Daly, L M Mann, and G Dall'Alba. 2011. "Being a Professional: Three Lenses into Design Thinking, Acting, and Being." Design Studies 32 (3): 255-91.

Alexiou, K, T Zamenopoulos, J H Johnson, and S J Gilbert. 2009. "Exploring the Neurological Basis of Design Cognition Using Brain Imaging: Some Preliminary Results." Design Studies 30 (6): 623-47. https://doi.org/10.1016/j.destud.2009.05.002.

Ashcraft, K. 2013. “The Glass Slipper: 'Incorporating' Occupational Identity in 
Management Studies." Academy of Management Review 38 (1): 6-31.

https://doi.org/105465/amr20100219.

Atuahene-Gima, K. 2010. "The Vital Role of Problem-Solving Competence in New Product Success*." Journal of Product Innovation Management 61 (2): 21-98. https://doi.org/10.1111/j.1540-5885.2010.00782.x.

Badke-Schaub, P, A Neumann, K Lauche, and S Mohammed. 2007. "Mental Models in Design Teams: A Valid Approach to Performance in Design Collaboration?" CoDesign 3 (1): 5-20. https://doi.org/10.1080/15710880601170768.

Ball, L J, and T C Ormerod. 2000. "Applying Ethnography in the Analysis and Support of Expertise in Engineering Design.” Design Studies 21 (4): 403-21. http://sfx4.exlibrisgroup.com:9003/bath?sid=google.

Barnett, R. 2011. Being a University. Abingdon, UK: Routledge.

Baumeister, R F, and M Muraven. 1996. "Identity as Adaptation to Social, Cultural, and Historical Context." In Journal of Adolescence, 19:405-16. https://doi.org/10.1006/jado.1996.0039.

Blessing, L T M, and A Chakrabarti. 2009. DRM, a Design Research Methodology. New York: Springer.

Bonsiepe, G. 1994. “A Step Towards the Reinvention of Graphic Design.” Design Issues 10 (1): 47. https://doi.org/10.2307/1511655.

Brunello, G, and M Schlotter. 2011. "Non Cognitive Skills and Personality Traits: Labour Market Relevance and Their Development in Education \& Training Systems." IZA Discussion Paper, no. 5743: 46.

Bucciarelli, L L. 1988. "An Ethnographic Perspective on Engineering Design.” Design Studies 9 (3): 159-68. http://sfx4.exlibrisgroup.com:9003/bath?sid=google.

- 2002. "Between Thought and Object in Engineering Design." Design Studies 23 (3): 219-31. http://www.sciencedirect.com/science/article/B6V2K-44X01D76/2/2c86a906dcbf2fd046bfcbdc93bba374.

Bucciarelli, L L, and S Kuhn. 1997. "Engineering Education and Engineering Practice: Improving the Fit." In Between Craft and Science : Technical Work in U.S. Settings, edited by Stephen R Barley and Julian E Orr. London: Cornell University Press.

Burke, C S, K C Stagl, C Klein, G F Goodwin, E Salas, and S M Halpin. 2006. "What Type of Leadership Behaviors Are Functional in Teams? A Meta-Analysis." Leadership Quarterly 17 (3): 288-307. https://doi.org/10.1016/j.leaqua.2006.02.007.

Brunhaver, S. R., Korte, R. F., Barley, S. R., \& Sheppard, S. D. (2011). Bridging The Gaps Between Engineering Education and Practice. In R. B. Freeman \& H. Salzman (Eds.), U.S. Engineering in a Global Economy. University of Chicago Press.

Cañavate, J, M J Lis Arias, and J M Casasús. 2015. "Implementing Social Awareness into Engineering Curricula.” In International Perspectives on Engineering Education, 457-75. https://doi.org/10.1007/978-3-319-16169-3_22.

Cannon-Bowers, J A, and E Salas. 2001. "Reflections on Shared Cognition." Journal of Organizational Behavior 22 (2): 195-202. https://doi.org/10.1002/job.82.

Cardoso, C, P Badke-Schaub, and O Eris. 2016. "Inflection Moments in Design Discourse: How Questions Drive Problem Framing during Idea Generation." Design Studies 46: 59-78. https://doi.org/10.1016/j.destud.2016.07.002.

Christensen, L B, R B Johnson, and L A Turner. 2011. Research Methods, Design, and Analysis. 11th ed. Boston, USA: Pearson.

Coates, G, A H B Duffy, I Whitfield, and W Hills. 2004. "Engineering Management: 
Operational Design Coordination." Journal of Engineering Design 15 (5): 433-46. https://doi.org/10.1080/09544820410001697145.

Cohen-Scali, V. 2003. "The Influence of Family, Social, and Work Socialization on the Construction of the Professional Identity of Young Adults." Journal of Career Development 29 (4): 237-49. https://doi.org/10.1023/A:1022987428665.

Crafford, A, B G Adams, T Saayman, and C Vinkenburg. 2015. "The Process of Identity Work: Negotiating a Work Identity." In Conceptualising and Measuring Work Identity: South-African Perspectives and Findings, edited by Paul G.W. Jansen and Gert Roodt, 53-86. Dordrecht: Springer Netherlands. https://doi.org/10.1007/978-94-017-9242-4_3.

Crain, R W, D C Davis, D E Calkins, and K Gentili. 1995. "Establishing Engineering Design Competencies for Freshman/Sophomore Students." In Frontiers in Education Conference, 4d2.1-4d2.4. https://doi.org/10.1109/fie.1995.483234.

Cross, N. 1982. "Designerly Ways of Knowing." Design Studies 3 (4): 221-27. https://doi.org/10.1007/1-84628-301-9.

_. 2004. "Expertise in Design: An Overview." Design Studies 25 (5): 427. https://doi.org/10.1016/j.destud.2004.06.002.

Crossley, J, and P Vivekananda-Schmidt. 2009. "The Development and Evaluation of a Professional Self Identity Questionnaire to Measure Evolving Professional SelfIdentity in Health and Social Care Students.” Medical Teacher 31 (12): e603-7. https://doi.org/10.3109/01421590903193547.

Cruess, R L, S R Cruess, and Y Steinert. 2016. “Amending Miller's Pyramid to Include Professional Identity Formation.” Academic Medicine 91 (2): 180-85. https://doi.org/10.1097/ACM.0000000000000913.

D’Anjou, P. 2011. “An Alternative Model for Ethical Decision-Making in Design: A Sartrean Approach.” Design Studies 32 (1): 45-59. https://doi.org/10.1016/j.destud.2010.06.003.

Dahlgren, M A, T D Solbrekke, B Karseth, and S Nyström. 2014. "From University to Professional Practice: Students as Journeymen Between Cultures of Education and Work." In International Handbook of Research in Professional and PracticeBased Learning, edited by S Billett, C Harteis, and H Gruber, 461-84. https://doi.org/10.1007/978-94-017-8902-8_17.

Dall'Alba, G. 2009. "Learning Professional Ways of Being: Ambiguities of Becoming." Educational Philosophy and Theory 41 (1): 34-45. https://doi.org/10.1111/j.14695812.2008.00475.x.

Dent, M, and S Whitehead. 2001. "Configuring the 'New' Professional." In Managing Professional Identities: Knowledge, Performativities and the "new" Professional, edited by Mike Dent and Stephen Whitehead, 1st ed., 1-16. Taylor Francis.

Dong, A. 2009. The Language of Design: Theory and Computation. The Language of Design: Theory and Computation. Springer-Verlag London Limited. https://doi.org/10.1007/978-1-84882-021-0.

Elkjaer, B, and U Brandi. 2014. International Handbook of Research in Professional and Practice-Based Learning. Edited by Stephen Billett, Christian Harteis, and Hans Gruber. International Handbook of Research in Professional and PracticeBased Learning. Springer International Handbooks of Education. Dordrecht: Springer Netherlands. https://doi.org/10.1007/978-94-017-8902-8.

Etela, A. 2000. "Contextual and Strategic Knowledge in the Acquisition of Design Expertise." Learning and Instruction 10: 113-36.

Evetts, J. 2003. "The Sociological Analysis of Professionalism: Occupational Change in the Modern World." International Sociology 18 (2): 395-415. 
https://doi.org/10.1177/0268580903018002005.

Fayard, A L, I Stigliani, and B A Bechky. 2017. "How Nascent Occupations Construct a Mandate: The Case of Service Designers' Ethos." Administrative Science Quarterly 62 (2): 270-303. https://doi.org/10.1177/0001839216665805.

Fiorineschi, L, F Rotini, and P Rissone. 2016. "A New Conceptual Design Approach for Overcoming the Flaws of Functional Decomposition and Morphology." Journal of Engineering Design 27 (7): 438-68.

https://doi.org/10.1080/09544828.2016.1160275.

Freeman, R B, and H Salzman. 2019. "Bridging the Gaps between Engineering

Education and Practice." In U.S. Engineering in a Global Economy, edited by

Richard B. Freeman and Hal Salzman, 129-64. University of Chicago Press.

https://doi.org/10.7208/chicago/9780226468471.003.0005.

Garner, S. 2006. "Revealing Design Complexity: Lessons from the Open University." CoDesign 1 (4): 267-76. https://doi.org/10.1080/15710880500478387.

Godsey, S R. 2011. "Student Perceptions of Professional Identity and Cultural

Competence." ProQuest Dissertations and Theses. University of Minnesota.

https://search.proquest.com/docview/873812809?accountid=14548\%0Ahttps://jula c.hosted.exlibrisgroup.com/openurl/HKU_ALMA/SERVICES_PAGE??url_ver=Z 39.88-

2004\&rft_val_fmt=info:ofi/fmt:kev:mtx:dissertation\&genre $=$ dissertations $+\% 26+$ th eses\&sid=ProQ:ProQuest+Disse.

Goede, M De, E Spruijt, J Iedema, and W Meeus. 1999. "How Do Vocational and Relationship Stressors and Identity Formation Affect Adolescent Mental Health?" Journal of Adolescent Health 25 (1): 14-20. https://doi.org/10.1016/S1054139X(98)00136-0.

Gonçalves, M, C Cardoso, and P Badke-schaub. 2014. "What Inspires Designers? Preferences on Inspirational Approaches during Idea Generation." Design Studies 35 (1): 29-53. https://doi.org/10.1016/j.destud.2013.09.001.

Grace, S, and F Trede. 2013. "Developing Professionalism in Physiotherapy and Dietetics Students in Professional Entry Courses." Studies in Higher Education 38 (6): 793-806. https://doi.org/10.1080/03075079.2011.603410.

Haase, S. 2014. "Professional Identity and Role of the Engineer in a Challenged Society Empirical Investigation of Engineering Student Conceptions."

Hakatie, A, and T Ryynänen. 2007. "Managing Creativity: A Gap Analysis Approach to Identifying Challenges for Industrial Design Consultancy Services." Design Issues 23 (1): 28-46. https://doi.org/10.1162/desi.2007.23.1.28.

Haslam, S A, and N Ellemers. 2011. "Identity Processes in Organizations." In Handbook of Identity Theory and Research, edited by Seth J. Schwartz, Koen Luyckx, and Vivian L. Vignoles, 715-44. New York, NY: Springer New York. https://doi.org/10.1007/978-1-4419-7988-9_30.

Helfat, C E, and J A Martin. 2015. "Dynamic Managerial Capabilities: Review and Assessment of Managerial Impact on Strategic Change." Journal of Management 41 (5): 1281-1312. https://doi.org/10.1177/0149206314561301.

Ibarra, H. 1999. "Provisional Selves: Experimenting with Image and Identity in Professional Adaptation." Administrative Science Quarterly 44 (4): 764-91. https://doi.org/10.2307/2667055.

Khapova, S N, M B Arthur, C P M Wilderom, and J S Svensson. 2007. "Professional Identity as the Key to Career Change Intention." Career Development International 12 (7): 584-95. https://doi.org/10.1108/13620430710834378.

Khorshidi, M, J J Shah, and J Woodward. 2014. "Applied Tests of Design Skills_-Part 
III: Abstract Reasoning.” Journal of Mechanical Design 136 (10): 101101. https://doi.org/10.1115/1.4027986.

Kim, Y S, S T Jin, and S W Lee. 2011. "Relations between Design Activities and Personal Creativity Modes." Journal of Engineering Design 22 (4): 235-57. https://doi.org/10.1080/09544820903272867.

Klimoski, R, and S Mohammed. 1994. "Team Mental Model: Construct or Metaphor?" Journal of Management 20 (2): 403-37. https://doi.org/10.1177/014920639402000206.

Knippenberg, D van, B van Knippenberg, D De Cremer, and M A Hogg. 2004. "Leadership, Self, and Identity: A Review and Research Agenda." Leadership Quarterly 15 (6): 825-56. https://doi.org/10.1016/j.leaqua.2004.09.002.

Koskinen, I, T Mattelmäki, and K Battarbee. 2003. Empathic Design. MIT Press. IT Press.

Kouprie, M, and F S Visser. 2009. "A Framework for Empathy in Design: Stepping into and out of the User's Life." Journal of Engineering Design 20 (5): 437-48. https://doi.org/10.1080/09544820902875033.

Krawczyk, E, and M Murphy. 2012. "The Challenge of Educating Engineers for a Close, Crowded and Creative World." In Engineering, Development and Philosophy, edited by Steen Hyldgaard Christensen, Carl Mitcham, Bocong Li, and Yanming An, 109-22. Philosophy of Engineering and Technology. Dordrecht: Springer Netherlands. https://doi.org/10.1007/978-94-007-5282-5.

Kruger, C, and N Cross. 2006. "Solution Driven versus Problem Driven Design: Strategies and Outcomes." Design Studies 27 (5): 527-48. https://doi.org/10.1016/j.destud.2006.01.001.

Kunrath, K, P Cash, and J Li-Ying. 2016. "Designer's Identity: Personal Attributes and Design Skills.” In Design 2016, DS 84:1729-40. Dubrovnik, Croatia.

_. 2017. "Designer's Identity: Development of Personal Attributes and Design Skills over Education." In ICED 17 International Conference on Engineering Design, 8:419-28. vancouver, Canada.

Lawson, B. 2005. How Designers Think. 4th editio. Architectural Press. https://doi.org/10.1017/CBO9781107415324.004.

Lewis, W P, and E Bonollo. 2002. "An Analysis of Professional Skills in Design: Implications for Education and Research." Design Studies 23 (4): 385-406. https://doi.org/10.1016/S0142-694X(02)00003-0.

Lichtenstein, G, H G Loshbaugh, B Claar, H L Chen, K Jackson, and S D Sheppard. 2009. "An Engineering Major Does Not (Necessarily) an Engineer Make: Career Decision Making Among Undergraduate Engineering Majors." Journal of Engineering Education 98 (3): 227-34. https://doi.org/10.1002/j.21689830.2009.tb01021.x.

Littlejohn, D. 2011. "Anticipation and Action in Graduate-Level Design Programs: Building a Theory of Relationships Among Academic Culture, Professional Identity and the Design of the Teaching Environment."

Marquardt, M K, A P Gantman, P M Gollwitzer, and G Oettingen. 2016. "Incomplete Professional Identity Goals Override Moral Concerns." Journal of Experimental Social Psychology 65 (July): 31-41. https://doi.org/10.1016/j.jesp.2016.03.001.

McLaren, S V, and K Stables. 2008. "Exploring Key Discriminators of Progression: Relationships between Attitude, Meta-Cognition and Performance of Novice Designers at a Time of Transition.” Design Studies 29 (2): 181-201. https://doi.org/10.1016/j.destud.2007.10.001.

Miles, M B, and A M Huberman. 1994. Qualitative Data Analysis: An Expanded 
Sourcebook. Thousand Oaks, California: Sage.

http://sfx4.exlibrisgroup.com:9003/bath?sid=google.

Mir, F A, and A H Pinnington. 2014. "Exploring the Value of Project Management: Linking Project Management Performance and Project Success." International Journal of Project Management 32 (2): 202-17. https://doi.org/10.1016/j.ijproman.2013.05.012.

Murphy, M, S Chance, and E Conlon. 2015. "Designing the Identities of Engineers." In Philosophy of Engineering and Technology, edited by Steen Hyldgaard Christensen, Christelle Didier, Andrew Jamison, Martin Meganck, Carl Mitcham, and Byron Newberry, 21:41-64. https://doi.org/10.1007/978-3-319-16172-3_3.

Neuman, L. 1997. Social Research Methods: Qualitative and Quantitative Approaches. Boston, USA: Allyn and Bacon.

Neumann, A. 2012. "Designerly Ways of Sharing." Delft, Netherlands: Delft University of Technology.

Oxman, R. 1990. "Prior Knowledge in Design: A Dynamic Knowledge-Based Model of Design and Creativity." Design Studies 11 (1): 17-28.

https://doi.org/10.1016/0142-694X(90)90011-Z.

_. 1999. "Educating the Designerly Thinker.” Design Studies 20 (2): 105-22. https://doi.org/10.1016/S0142-694X(98)00029-5.

Patton, M Q. 2001. Qualitative Research \& Evaluation Methods. Thousand Oaks, CA: Sage.

Poell, R F, and F J Van Der Krogt. 2014. "The Role of Human Resource Development in Organizational Change: Professional Development Strategies of Employees, Managers and HRD Practitioners." In International Handbook of Research in Professional and Practice-Based Learning, edited by Stephen Billett, Christian Harteis, and Hans Gruber, 1043-70. Dordrecht. https://doi.org/10.1007/978-94017-8902-8_38.

Rentsch, J R, and R J Hall. 1994. "Members of Great Teams Think Alike: A Model of Team Effectiveness and Schema Similarity among Team Members." In Advances in Interdisciplinary Studies of Work Teams: Theories of Self-Managing Work Teams, Vol. 1, edited by M M Beyerlein and D A Johnson, 223-61.

Robinson, M A, P R Sparrow, C Clegg, and K Birdi. 2005. "Design Engineering Competencies: Future Requirements and Predicted Changes in the Forthcoming Decade." Design Studies 26 (2): 123-53.

http://www.sciencedirect.com/science/article/B6V2K-4DVBHWV1/2/96d4f7636b96321175e0838a2d66bb13.

Robson, C, and K McCartan. 2011. Real World Research. 4th ed. Chichester: Wiley. http://sfx4.exlibrisgroup.com:9003/bath?sid=google.

Rodger, T F. 1963. “Affect Imagery Consciousness." British Journal of Psychiatry 109 (463): 837-837. https://doi.org/10.1192/bjp.109.463.837.

Seitamaa-Hakkarainen, P, and K Hakkarainen. 2001. "Composition and Construction in Experts' and Novices' Weaving Design.” Design Studies 22 (1): 47-66.

Shanteau, J. 1988. "Psychological Characteristics and Strategies of Expert Decision Makers." Acta Psychologica 68 (1-3): 203-15. https://doi.org/10.1016/00016918(88)90056-X.

Sharma, S, and M Sharma. 2010. "Self, Social Identity and Psychological Well-Being." Psychological Studies 55 (2): 118-36. https://doi.org/10.1007/s12646-010-0011-8.

Skorikov, V B, and F W Vondracek. 2011. “Occupational Identity.” In Handbook of Identity Theory and Research, edited by Vivian L. Vignoles, Seth J. Schwartz, and Koen Luyckx, 693-714. New York, NY: Springer New York. 
https://doi.org/10.1007/978-1-4419-7988-9_29.

Smith, K M. 2015. "Conditions Influencing the Development of Design Expertise: As Identified in Interior Design Student Accounts." Design Studies 36 (C): 77-98. https://doi.org/10.1016/j.destud.2014.09.001.

Sonnenwald, D H. 1996. "Communication Roles That Support Collaboration during the Design Process.” Design Studies 17 (3): 277-301. https://doi.org/10.1016/0142694X(96)00002-6.

Sun, Q, A Williams, and M Evans. 2011. “A Theoretical Design Management Framework." Design Journal 14 (1): 112-32. https://doi.org/10.2752/175630610X12877385838885.

Teixeira, M A P, and W B Gomes. 2000. "Autonomous Career Change among Professionals: An Empirical Phenomenological Study.” Journal of Phenomenological Psychology 31 (1): 78-96. https://doi.org/10.1163/156916200746265.

Tracey, M W, and A Hutchinson. 2013. "Developing Designer Identity Through Reflection." Educational Technology 53 (2): 28-32.

—. 2016. "Uncertainty, Reflection, and Designer Identity Development." Design Studies 42: 86-109. https://doi.org/10.1016/j.destud.2015.10.004.

Trede, F. 2012a. "Developing a Critical Professional Identity: Engaging Self in Practice." In Practice-Based Education: Perspectives and Strategies, 3rd ed., 2740. Rotterdam, The Netherlands: Sense Publishers. 2012b. "Role of Work-Integrated Learning in Developing Professionalism and Professional Identity." Asia-Pacific Journal of Cooperative Education 13 (3): 15967. http://www.apjce.org/files/APJCE_13 3 159_167.pdf.

Tynjälä, P, and J M Newton. 2014. "Transitions to Working Life: Securing Professional Competence." In International Handbook of Research in Professional and Practice-Based Learning, edited by Stephen Billett, Christian Harteis, and Hans Gruber, 513-33. Dordrecht: Springer International Handbooks of Education. https://doi.org/10.1007/978-94-017-8902-8_19.

Ulrich, K T, and S D Eppinger. 2003. Product Design and Development. Vol. 5th. New York, USA: MvGraw-Hill. http://sfx4.exlibrisgroup.com:9003/bath?sid=google.

Vaishya, R, S Jha, and D K Srivastava. 2016. "Revisiting Managerial CompetenciesLiterature Review." International Journal of Innovative Research and Development 5 (4): 328-38.

Wells, P, P Gerbic, I Kranenburg, and J Bygrave. 2009. "Professional Skills and Capabilities of Accounting Graduates: The New Zealand Expectation Gap?" Accounting Education 18 (4-5): 403-20. https://doi.org/10.1080/09639280902719390.

Wenzel, L H, and K Kraiger. 1997. Conceptual Development and Empirical Evaluation of Measures of Shared Mental Models as Indicators of Team Effectiveness. Edited by Michael T. Brannick, Eduardo Salas, and Carolyn W. Prince. Team Performance Assessment and Measurement Theory Methods and Applications. Psychology Press.

http://books.google.co.kr/books?hl=en\&lr=\&id=wWcxKMyUDl4C\&oi=fnd\&pg= PA63\&dq $=$ The + measurement + of + team + mental + models: + We + have + no + shared $+\mathrm{s}$ chema\&ots=qB1dljKSAZ\&sig=UcfqqIgvy9MxFi3N4xPaVPqCbz0.

Weth, R von der. 1999. "Design Instinct?-The Development of Individual Strategies." Design Studies 20 (5): 453-63. https://doi.org/10.1016/s0142-694x(99)00021-6.

Williams, J. 2013. Constructing New Professional Identities: Career Changers in Teacher Education. Constructing New Professional Identities: Career Changers in 
Teacher Education. Rotterdam, The Netherlands: Sense Publishers. https://doi.org/10.1007/978-94-6209-260-0.

Wilpert, B. 2007. "Psychology and Design Processes." Safety Science 45 (1-2): $293-$ 303. https://doi.org/10.1016/j.ssci.2006.08.016.

Worthington, M, Y Salamonson, R Weaver, and M Cleary. 2013. "Predictive Validity of the Macleod Clark Professional Identity Scale for Undergraduate Nursing Students." Nurse Education Today 33 (3): 187-91. https://doi.org/10.1016/j.nedt.2012.01.012.

Yang, M Y, M You, and F C Chen. 2005. "Competencies and Qualifications for Industrial Design Jobs: Implications for Design Practice, Education, and Student Career Guidance.” Design Studies 26 (2): 155-89. https://doi.org/10.1016/j.destud.2004.09.003.

Zhang, D. 2015. "Industrial Designers: Are You Ready for Foreign Markets? Assessing Designer Confidence and Prediction Accuracy in a Transnational Marketing Context." Creativity and Innovation Management 24 (3): 449-63. https://doi.org/10.1111/caim.12142. 


\section{Appendix}

\section{Interview guide for open-ended questions}

1. What do you think is the role of a designer 'generically'? And in the context of your company, what is there role?

2. What do you think is the most important characteristics of a Designer in general? And for your company?

3. How do you see the influence of Design Skills and Personal Attributes on the perceived competence of a designer?

4. If you think on the best designers that you got to know or worked with, which characteristics of them made you perceive them as inspiring?

5. In the same sense, if you think on designers that you met or worked with and somehow you thought that, maybe, they were nor really suitable for that job. What made you feel like that?

\section{Interview questionnaire for importance attribution to DPI elements}

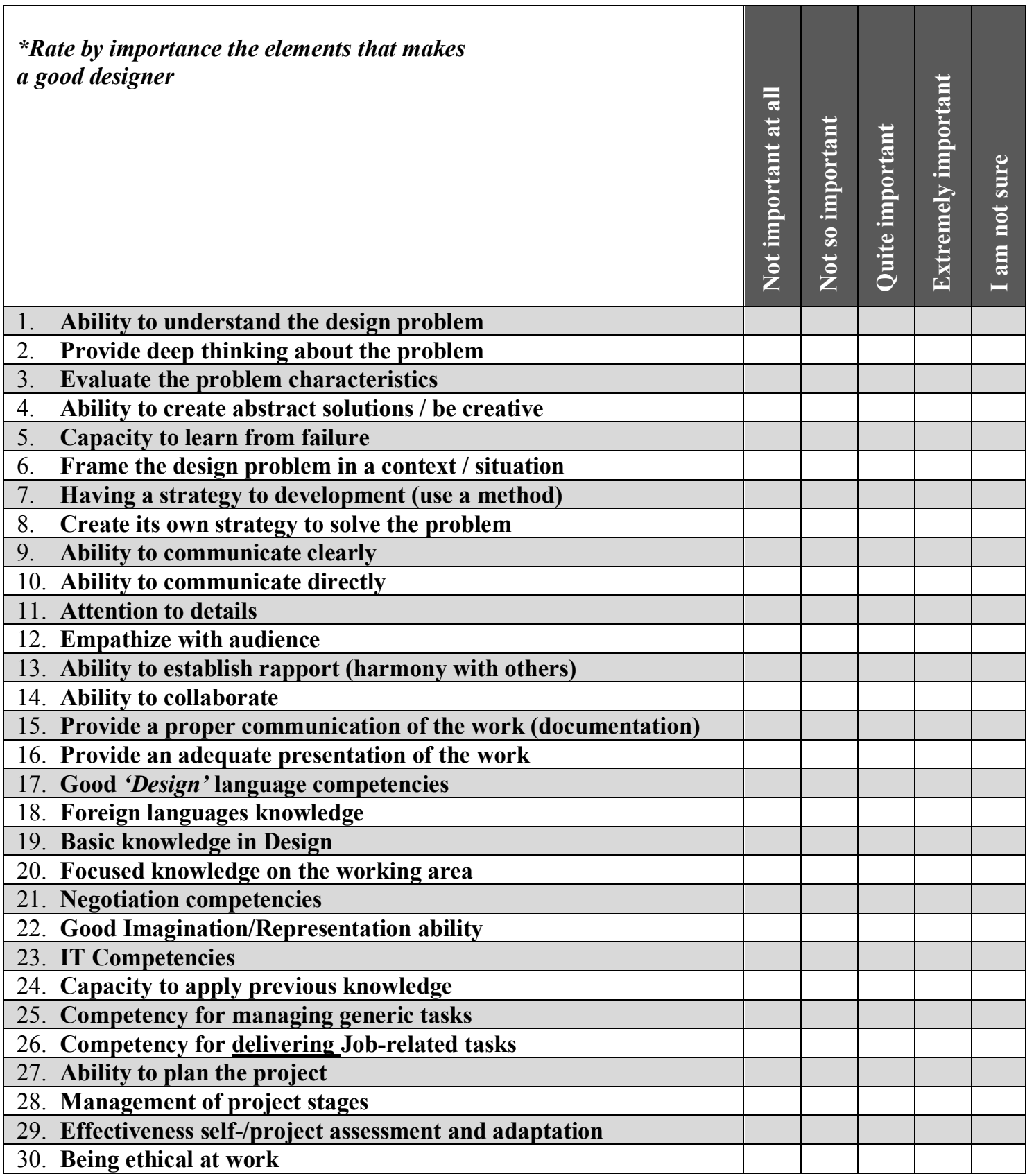




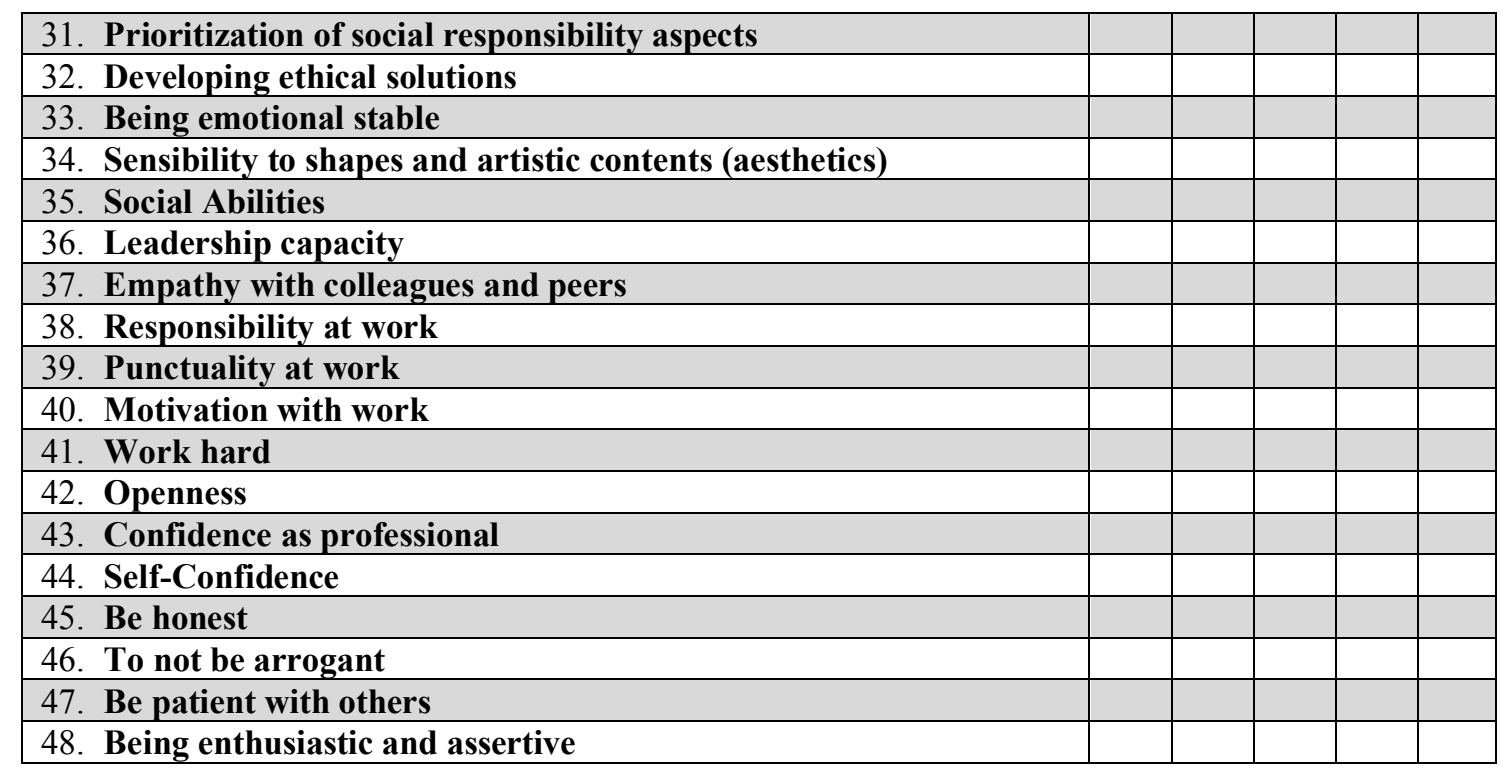

* Provide any other competency that you think is important but is not on the list

\section{Representativeness of the questionnaire items per DPI category}

\begin{tabular}{|l|l|l|l|l|l|l|l|l|l|}
\hline CA & $1,2,3$ & EK & $17,18,19$ & CO & 16,43 & EP & $37,45,46$ & OP & 24,42 \\
\hline CS & $5,6,7$ & PK & $20,21,22,23$ & SC & 15,44 & ET & $30,31,32$ & RE & 38,39 \\
\hline PC & $9,10,11$ & MC & 25,26 & CR & 4,8 & LE & 36,47 & SA & 35,48 \\
\hline IC & $12,13,14$ & PM & $27,28,29$ & EM & 33,34 & MO & 40,41 & & \\
\hline
\end{tabular}


Descriptive statistics for the importance attribution to DPI elements

\begin{tabular}{|r|l|l|l|l|l|l|l|l|l|}
\hline & \multicolumn{3}{l}{ Professors } & \multicolumn{2}{l}{ Managers } & \multicolumn{2}{l}{ Differences } \\
\hline & mean & var & mean & var & mean & var & D-P & D-M & $P$-M \\
\hline CA & 3,37 & 0,05 & 3,33 & 0,06 & 3,36 & 0,05 & $-0,01$ & 0,03 & 0,04 \\
\hline CS & 3,15 & 0,09 & 3,08 & 0,08 & 3,18 & 0,01 & 0,03 & 0,10 & 0,07 \\
\hline PC & 3,04 & 0,16 & 3,17 & 0,06 & 3,27 & 0,05 & 0,23 & 0,11 & $-0,13$ \\
\hline IC & 3,19 & 0,08 & 3,11 & 0,17 & 3,46 & 0,06 & 0,27 & 0,35 & 0,08 \\
\hline EK & 2,55 & 0,07 & 2,61 & 0,27 & 2,89 & 0,13 & 0,33 & 0,28 & $-0,06$ \\
\hline PK & 2,91 & 0,11 & 3,08 & 0,12 & 3,06 & 0,07 & 0,16 & $-0,02$ & $-0,18$ \\
\hline MC & 2,89 & 0,06 & 3,20 & 0,04 & 3,10 & 0,01 & 0,21 & $-0,10$ & $-0,31$ \\
\hline PM & 2,92 & 0,10 & 3,01 & 0,08 & 3,03 & 0,05 & 0,11 & 0,02 & $-0,09$ \\
\hline CO & 3,17 & 0,01 & 3,42 & 0,01 & 3,29 & 0,00 & 0,12 & $-0,13$ & $-0,25$ \\
\hline SC & 2,87 & 0,07 & 3,00 & 0,03 & 3,18 & 0,01 & 0,31 & 0,18 & $-0,13$ \\
\hline CR & 3,24 & 0,11 & 3,25 & 0,34 & 3,09 & 0,16 & $-0,15$ & $-0,16$ & $-0,01$ \\
\hline EM & 2,71 & 0,08 & 2,75 & 0,01 & 2,55 & 0,20 & $-0,16$ & $-0,20$ & $-0,04$ \\
\hline EP & 3,13 & 0,01 & 3,21 & 0,04 & 3,24 & 0,02 & 0,11 & 0,03 & $-0,08$ \\
\hline ET & 2,90 & 0,01 & 2,33 & 0,02 & 2,85 & 0,01 & $-0,05$ & 0,51 & 0,56 \\
\hline LE & 2,72 & 0,01 & 2,83 & 0,03 & 2,68 & 0,02 & $-0,04$ & $-0,15$ & $-0,11$ \\
\hline MO & 3,18 & 0,37 & 3,25 & 0,17 & 3,21 & 0,37 & 0,03 & $-0,04$ & $-0,07$ \\
\hline OP & 3,28 & 0,01 & 3,58 & 0,01 & 3,60 & 0,01 & 0,32 & 0,02 & $-0,30$ \\
\hline RE & 2,71 & 0,18 & 3,25 & 0,06 & 3,14 & 0,02 & 0,42 & $-0,11$ & $-0,54$ \\
\hline SA & 3,18 & 0,00 & 3,42 & 0,06 & 3,41 & 0,00 & 0,23 & $-0,01$ & $-0,24$ \\
\hline
\end{tabular}

\section{Example of Concept map built during an interview session}

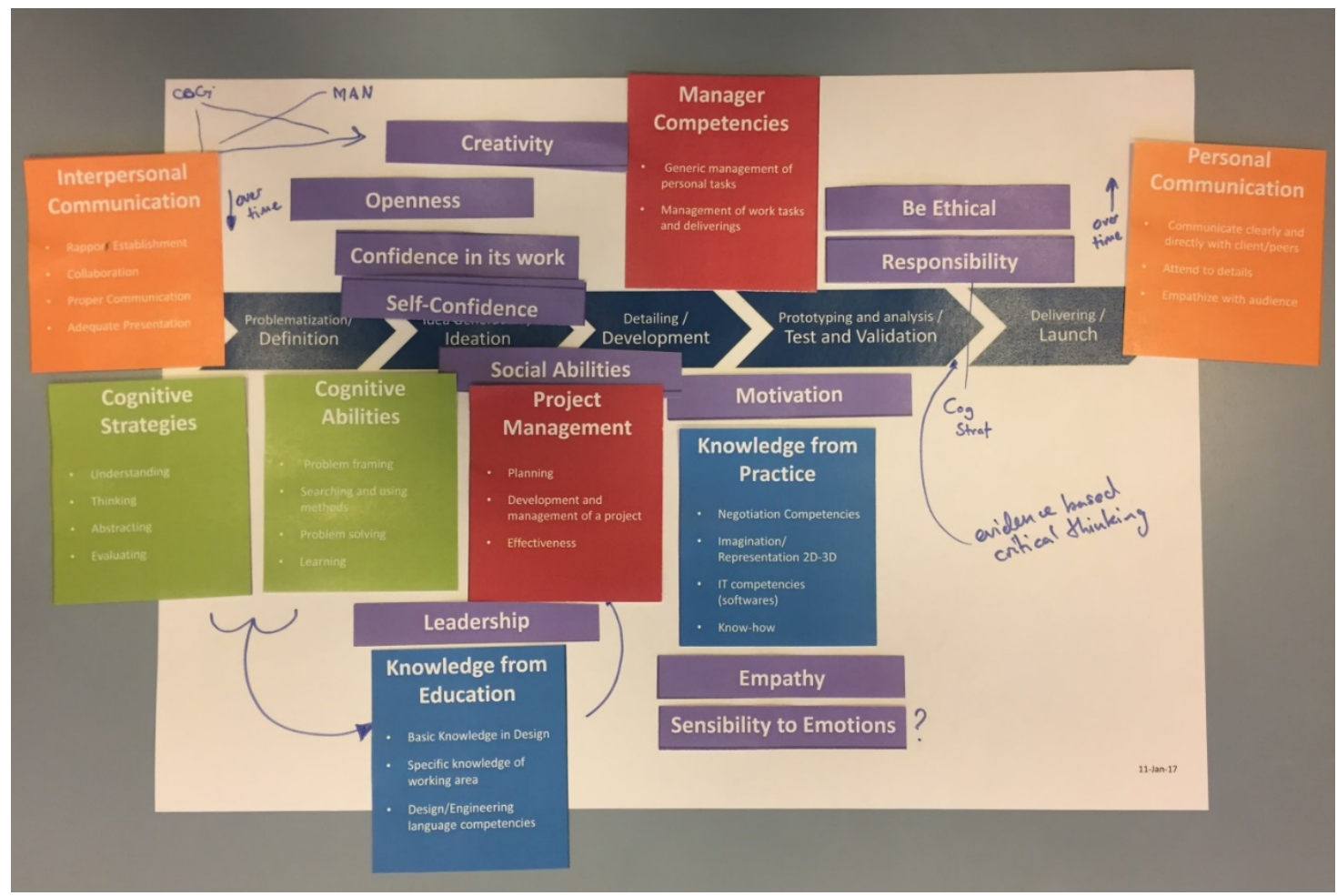


Ranking from response means and average variances

\begin{tabular}{c|ccc|ccc}
\multicolumn{1}{c}{ PROF (1) } & MAN (2) & DES (3) & VAR (P) & VAR (M) & VAR (D) \\
\hline CA & 3,37 & 3,33 & 3,36 & 0,05 & 0,06 & 0,05 \\
CS & 3,15 & 3,08 & 3,18 & 0,09 & 0,08 & 0,01 \\
PC & 3,04 & 3,17 & 3,27 & 0,16 & 0,06 & 0,05 \\
IC & 3,19 & 3,11 & 3,46 & 0,08 & 0,17 & 0,06 \\
EK & 2,55 & 2,61 & 2,89 & 0,07 & 0,27 & 0,13 \\
PK & 2,91 & 3,08 & 3,06 & 0,11 & 0,12 & 0,07 \\
MC & 2,89 & 3,20 & 3,10 & 0,06 & 0,04 & 0,01 \\
PM & 2,92 & 3,01 & 3,03 & 0,10 & 0,08 & 0,05 \\
CO & 3,17 & 3,42 & 3,29 & 0,01 & 0,01 & 0,00 \\
SC & 2,87 & 3,00 & 3,18 & 0,07 & 0,03 & 0,01 \\
CR & 3,24 & 3,250 & 3,09 & 0,11 & 0,34 & 0,16 \\
EM & 2,71 & 2,75 & 2,55 & 0,08 & 0,01 & 0,20 \\
EP & 3,13 & 3,21 & 3,24 & 0,01 & 0,04 & 0,02 \\
ET & 2,90 & 2,33 & 2,85 & 0,01 & 0,02 & 0,01 \\
LE & 2,72 & 2,83 & 2,68 & 0,01 & 0,03 & 0,02 \\
MO & 3,18 & 3,25 & 3,21 & 0,37 & 0,17 & 0,37 \\
OP & 3,28 & 3,58 & 3,60 & 0,01 & 0,01 & 0,01 \\
RE & 2,71 & 3,25 & 3,14 & 0,18 & 0,06 & 0,02 \\
SA & 3,18 & 3,42 & 3,41 & 0,00 & 0,06 & 0,00
\end{tabular}




\section{Sharedness (\% of respondents) for DPI elements verses the NPD process}

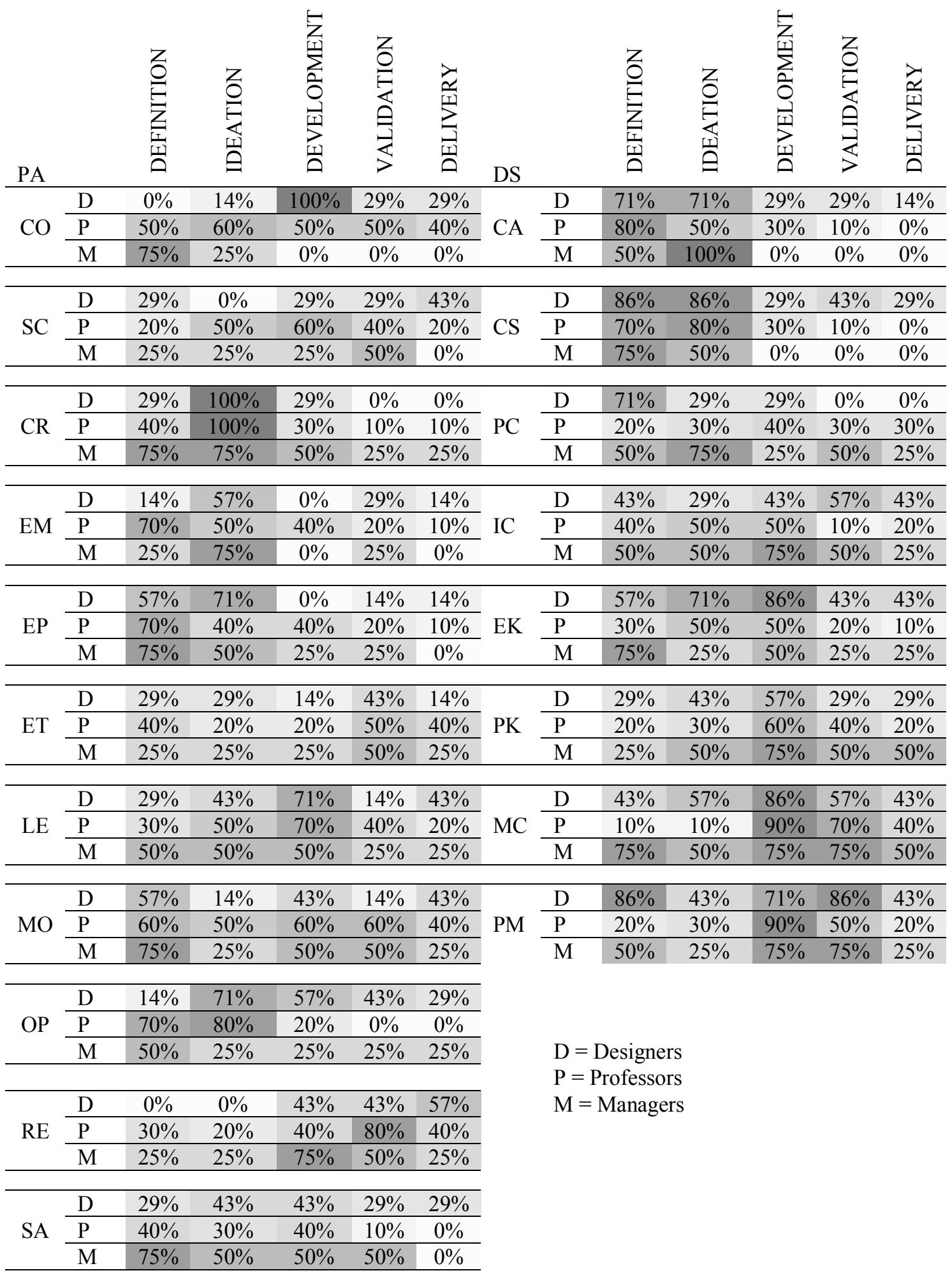


i) Interviewees' coding and experience

\begin{tabular}{llllll} 
& Professors & & Managers & & Designers \\
\hline code & Experience & code & Experience & code & Experience \\
\hline P1 & 19 years & M1 & 2 years & D1 & 4 years \\
\hline P2 & 5 years & M2 & 2 years & D2 & 2 years \\
\hline P3 & 5 years & M3 & 20 years & D3 & 4 years \\
\hline P4 & 2 years & M4 & 5 years & D4 & 2 years \\
\hline P5 & 10 years & M5 & 7 years & D5 & 2 years
\end{tabular}

ii) Thematic Analysis and quantification responses that mention each theme

\begin{tabular}{|c|c|c|c|c|c|}
\hline \multirow{2}{*}{$\begin{array}{l}\text { Colour } \\
\text { code }\end{array}$} & \multirow[b]{2}{*}{ Themes } & \multirow[b]{2}{*}{ Description of meaning } & \multicolumn{3}{|c|}{ Nr. of responses } \\
\hline & & & $P$ & $M$ & $D$ \\
\hline & Creativity & $\begin{array}{l}\text { Sentences referring to brilliance, mind-set, } \\
\text { creativity, intention, or multidisciplinary capacity }\end{array}$ & $32^{\star}$ & 24 & 18 \\
\hline & Technique & $\begin{array}{c}\text { Sentences referring to practice, } \\
\text { design skills, methods or technical abilities }\end{array}$ & 17 & 23 & $20^{\star}$ \\
\hline & Rapport & $\begin{array}{l}\text { Sentences referring to communication, } \\
\text { collaboration, interaction, or empathy }\end{array}$ & 11 & $25^{\star}$ & 11 \\
\hline
\end{tabular}

\section{iii) Number of interviewees that mentioned aspects of each theme}

A. Professors

\begin{tabular}{|c|c|c|c|c|c|c|c|c|c|}
\hline & \multicolumn{3}{|c|}{ A. Professors } & \multicolumn{3}{|c|}{ B. Managers } & \multicolumn{3}{|c|}{ C. Designers } \\
\hline & 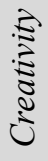 & $\frac{\sqrt{n}}{3}$ & 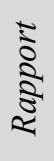 & 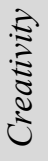 & $\frac{\sqrt{3}}{3}$ & 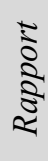 & 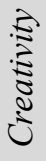 & $\frac{\sqrt{3}}{3}$ & 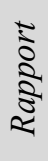 \\
\hline Role of the Designer & 4 & 3 & 0 & 1 & 3 & 3 & 3 & 3 & 1 \\
\hline Impact on society & 4 & 0 & 2 & 3 & 1 & 1 & 1 & 2 & 1 \\
\hline $\begin{array}{l}\text { Values at work } \\
\mathrm{P} \text { and } \mathrm{D}^{*}-\text { on teaching } \\
\mathrm{M} \text { and } \mathrm{D}-\text { role at work }\end{array}$ & 4 & 2 & 0 & 1 & 3 & 4 & 1 & $2+1 *$ & 2 \\
\hline Most important Characteristics & 4 & 2 & 3 & 3 & 5 & 5 & 3 & 4 & 1 \\
\hline IDEAL & 4 & 3 & 3 & 5 & 3 & 3 & 2 & 2 & 2 \\
\hline INSPIRING & 5 & 3 & 0 & 4 & 2 & 4 & 4 & 3 & 1 \\
\hline Undesirable characteristics & 3 & 2 & 1 & 4 & 1 & 3 & 1 & 2 & 3 \\
\hline $\begin{array}{l}\text { Balance between } \\
\text { PA and DS }\end{array}$ & 4 & 2 & 2 & 3 & 5 & 2 & 3 & 1 & 0 \\
\hline
\end{tabular}

